\title{
Lithic raw material in the Cantabrian region: Dialectical relationship between flint and quartzite in the Palaeolithic record
}

\author{
Alejandro Prieto ${ }^{1,2}$, Alvaro Arrizabalaga ${ }^{2}$, Iñaki Yusta ${ }^{3}$ \\ 1. Institute of Prehistory and Protohistory, Department of Classical World and Asian Cultures, Friederich- \\ Alexander University of Erlangen-Nürnberg (FAU). Kochstrasse, 4/18, D-91054 Erlangen, Germany. \\ Email: alejandro.de.prieto@fau.de, alejandro.prieto@ehu.eus \\ 2. Department of Geography, Prehistory and Archaeology, University of the Basque Country (UPV/EHU), \\ Tomás y Valiente s/n. 01006 Vitoria-Gasteiz, Spain. Email: alvaro.arrizabalaga@ehu.eus \\ 3. Department of Mineralogy and Petrology, University of the Basque Country (UPV/EHU), Barrio Sarrena s/n, \\ 48940 Leioa, Biscay, Spain. Email: i.yusta@ehu.eus
}

\begin{abstract}
The increase, in quantitative and qualitative terms, of research attending to the geological nature of rocks found in archaeological contexts is changing our perspectives about social and economic territories articulated by Palaeolithic societies in the Cantabrian Region. Practically the only raw material researched in a solid geoarchaeological approach in this area is flint. This paper addresses how the near absence of in-depth geoarchaeological research into raw materials other than flint is modifying our perception of the procurement and management mechanism of raw material in the Cantabrian Region during the Palaeolithic.

To consider this matter in depth, we present the bibliographic and quantitative analysis of 30 representative archaeological sites from the Cantabrian Region whose assemblages were described lithologically using basic and primary categories. The state of play depicts a geographic distribution of raw material in the Cantabrian Region where quartzite is associated with the western sector and flint with the east. Interconnected with this axis, there is a chronological tendency that promotes standardisation in the use of flint by Palaeolithic societies following a chronological order, from the older to the more recent periods. This information, and its contextualisation with the new perspectives resulting from the application of the geoarchaeological proposal used to understand flint procurement, allows us to understand the general tendencies of raw material distribution of the region. Especially, we can detect how the absence of geoarchaeological methodologies of other raw materials than flint has modified the perception of the economic and social dynamics articulated around raw material by Palaeolithic people. This bias does not only affect the geographical and chronological axes, emphasising information from the regions and periods where flint is represented, but also promotes the over-interpretation of long-distance procurement, therefore, building up narratives exclusively based on human mobility.

This situation has generated an incomplete and unbalanced picture of the procurement and management strategies followed by Palaeolithic societies because quartzite, the second most-often used lithic raw material, and other raw materials have only been studied using geoarchaeological methods within the last few years. This research finally points to the continuation of in-depth research
\end{abstract}

Published by the School of History, Classics and Archaeology, University of Edinburgh ISSN: 2055-0472. URL: http://journals.ed.ac.uk/lithicstudies/ 
of quartzite and other raw materials as the next steps to re-interpret the current paradigms about procurement and management of raw material by Palaeolithic societies, and, therefore, modify our perspectives of social and economic territories.

Keywords: lithic raw material; Cantabrian Region; Palaeolithic; quartzite; flint; state of play

\section{Introduction}

The characterisation of the rocks used by past humans has been a recurrent research topic in Prehistoric Archaeology since the beginnings of our scientific discipline. In the mid-19th century, the first prehistorians, mainly with geological academic training, made meticulous descriptions of the rocks they had found in archaeological contexts. Juan Vilanova y Piera, one of the pioneer prehistorians in the Iberian Peninsula, also Professor of Geology and Palaeontology, described prehistoric artefacts using archaeological and geological perspectives in an attempt to relate the artefacts with potential rock sources (Pelayo López \& Gonzalo Gutiérrez 2012: 145).

Studies of lithic raw materials intensified in the 1950s, supported by the development of Petrology and Geochemistry. The conclusions reached by those studies showed their potential for the determination of the provenance of lithic material. The first raw material to be studied was obsidian (Cann \& Renfrew 1964). This research was able to determine exchange routes for this material during the Neolithic, especially in the Mediterranean, Oceania and North America (e.g., Cann \& Renfrew 1964; Dixon et al. 1968; Polanyi 1957). In the following decades, standardised protocols for the analysis of lithic resources became common practice, the types of stone being characterised diversified, and the application of petrographic methods in different geographical and historical contexts became standardised (e.g., Binns \& McBryde 1969; Clark 1965; Durrani et al. 1970; Kowalski et al. 1972; Sieveking et al. 1972).

During the 1980s, new geographic areas were studied, new chronological frameworks started to be analysed and new raw materials were researched, especially after the pioneering work by Luedtke (1979) to characterise flint. The development, mainly in France, of research that addressed flint by A. Morala (1979; 1980; 1983), P. Y. Demars (1980), A. Masson (1981), Simonet (1981) and J. M. Geneste (1985) among others, also increased the quantity of information about raw material procurement. The relevant results these researchers proposed, and the reproducibility of the novel methods applied, increased the interest in flint identification in Palaeolithic contexts. Several pieces of research were produced in the following decade and new geographic areas were studied, mainly in Europe (e.g., Floss 1990; Jeske 1989; Normand 1986; Roebroeks 1988; Turq 1989). In the last twenty years of research, few and sometimes isolated scientific efforts in characterising raw materials for knapping processes other than flint or obsidian are widening the spectra of rocks analysed from geoarchaeological perspectives (e.g., Daffara et al. 2019; de Lombera-Hermida \& RodríguezRellán 2016; McHenry \& de la Torre 2018; Prieto et al. 2019a). In addition to this dynamic research, a clear qualitative development took place in the understanding of the behavioural, economic and social dynamics in Palaeolithic societies through the techno-typological analysis of lithic assemblages (Boëda 1994; Laplace 1972; 1987; Leroi-Gourhan 1964: 132144). Both perspectives converged on a better understanding of flint procurement and management by Palaeolithic societies (Andrefsky 1994; Roebroeks 1988; Turq 1996). Finally, theoretical approaches have modified the old culturalist perspectives into new ones, which are focused on the economic and social processes that relate prehistoric people and their environment (Bamforth 2006; Binford 1979; 1982; 1983; Brantingham 2003; Cronk 1991; Gould 1978; Kelly 1995: chapters 3 to 5 and chapter 9; Renfrew 1973: chapter 6; Vita-Finzi 1978). 
As already stated, although basic and primary lithological descriptions have been made since the mid-19th century, the first in-depth characterisation of raw material in the Iberian Peninsula started in the 1980s and the 1990s (e.g., Elorza \& Bustillo 1989; Mangado 1998; Tarriño 1998; Tarriño \& Elorza, 1989; Terradas 1995; Sarabia 1999). These pioneer studies focused on the characterisation of flint in Iberia, especially flint in the southern part of the Pyrenees and the Cantabrian Region. The petrological characterisation of flint at archaeological sites was based on its mineralogical composition, texture, fossil content and depositional environment (Tarriño \& Terradas 2013). In particular, the Cantabrian Region is one of the better researched-areas in Iberia where flint is being successfully studied. This has succeeded in determining the source areas of the flint brought to the sites by human groups and the establishment of regional lithic repositories (Herrero-Alonso et al. 2018; Tarriño et al. 2015; 2016). Additionally, it has improved the understanding of physical characteristics of the material, its behaviour in reduction and use (e.g., Calvo 2019; García-Rojas 2014; HerreroAlonso et al. 2020; Perales 2015; Tarriño 2006).

Within very recent years, studies have characterised the use of quartzite within archaeological contexts (Prieto 2018; Prieto et al. 2019a; 2020). However, this rock-type has not received the same level of methodological development as flint and obsidian, despite being one of the most-often used lithic raw materials in the European Palaeolithic. Only few and isolated studies have characterised quartzite from a geoarchaeological perspective (e.g., Straus et al. 1986). The absence of solid geoarchaeological protocols to characterise quartzite have hampered the expansion of studies addressing this rock in archaeological contexts. This has promoted a bias in understanding the strategies of procurement and management of this lithic material, which is only being overcome through the application of robust protocols. In particular, in northern Iberia, a region with a high density of prehistoric sites, quartzite is one of the most abundant raw materials at Palaeolithic sites. This is especially true for the western part of the Cantabrian Mountains.

The goal of this paper is to show the general overview of the distribution of raw material in the archaeological sites of the Cantabrian Region, and to understand how the absence of indepth characterisation of quartzites (and other raw materials) have modified our perception of Middle and Upper Palaeolithic economy and society. To do so, we present a quantitative analysis of raw materials in archaeological assemblages available from the bibliography. The state of the research proposed is also contextualised with the perspectives facilitated by the characterisation of flint in the Region (Tarriño 2001), the current state of flint studies (Tarriño et al., 2015) and the latest efforts made to characterise quartzite (Prieto et al. 2019a; 2020; 2021).

The terms 'quartzite' and 'flint', except when describing specific varieties, were used in this research as broad categories utilised by archaeologists and geologists (mainly in the field). Therefore, the term 'flint' includes here non-clastic sedimentary rocks, highly siliceous sedimentary, and microcrystalline rocks commonly named as chert or flint (e.g., Luedke, 1979; Tarriño et al. 2015). The term 'quartzite' includes sedimentary and metamorphic rocks with quartz containing over $90 \%$ of quartz, granular, and with a conchoidal fracture (e.g., Skolnick, 1965; Prieto et al. 2019a).

\section{Geographic and Geological setting}

This study is focused on the Cantabrian Region (north Spain). This area is in the northwestern part of Iberia. From a geographic perspective, it is a mixed zone that combines coastal and mountain landscapes. The former is related to the Bay of Biscay and the Cantabrian coast, which create the northern limit of this area. The latter refers to the Cantabrian Mountains, the western prolongation of the Pyrenees Mountain Range. In general, 
the highest mountains are situated in the central and western zones of this region, and they constitute a natural barrier to the south, where the northern Iberian Plateau is situated. These two essences of the Cantabrian Region, mountain and coast, together with Pleistocene glacier processes and, especially, active fluvial systems, create diverse geomorphologies and landforms such as high-altitude mountains, cliffs, gorges, talus slopes, plateaus, and closed or open valleys in a wide range of elevation reaching to more than 2,500 metres above sea level (Alonso et al. 2007). The river system, mainly in a south-north direction, promotes fragmentation of the terrain, and also of the Palaeolithic habitat.
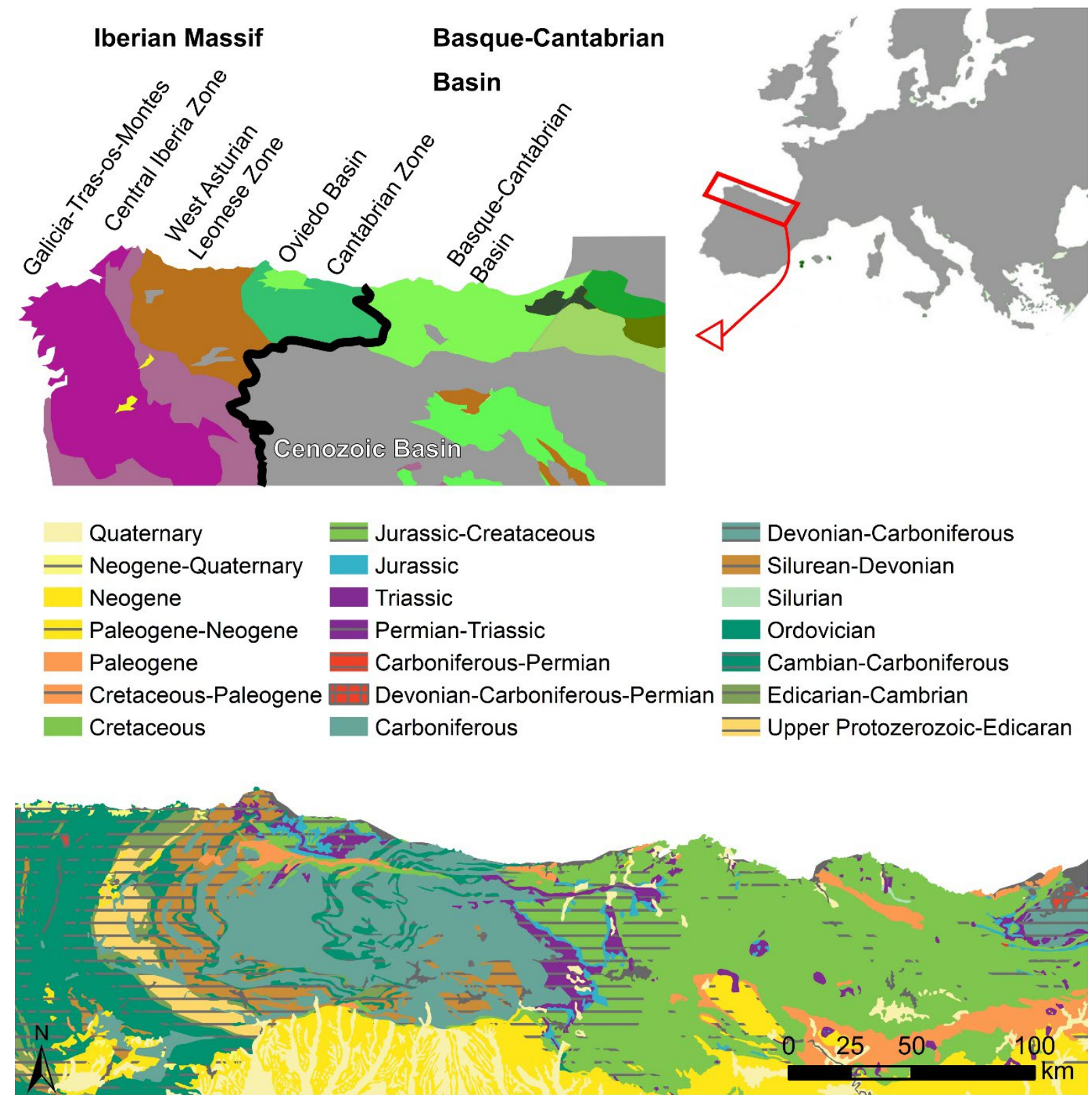

Figure 1. Main chrono-lithological strata and geological zones in the Cantabrian Region based on a 1:1,000,000 geological map (Álvaro et al. 1994). The black line divides the two main geological domains of the Cantabrian Region: the Iberian Massif and the Basque-Cantabrian basin.

From a geological standpoint, the research area is characterised by its complexity owing to the presence of multiple geological domains (Figure 1). In general terms, there is a precise gradation in the age of the geological formations from the western part to the eastern one, where more recent strata are situated. There is a primary division that splits this area in two: 
the western part, which is associated with the Palaeozoic Iberian Massif affected by the Variscan orogeny; and the eastern one, associated with the Pyrenees and affected by Alpine orogeny. The former is formed by the West Asturian-Leonese Zone and the Cantabrian Zone (Pérez-Estaún et al., 2004: 22-25). The age of these strata ranges from Precambrian (associated mainly with the western part) to the Permian. A complex geological history affects the area, especially as a result of the impact of the Variscan orogeny during the Carboniferous (Bastida, 2004: 25-26). The lithologies are varied too, with the presence of old massive siliceous outcrops affected, or not affected, by metamorphic processes, shales (lutites), and calcareous and conglomerate formations. The second domain is the Pyrenees basin. In the Cantabrian Region, this area is called the Basque-Cantabrian Basin, composed by Mesozoic materials characterised by calcareous formations together with sand-shale formations. The effect of metamorphism in this area is very limited, and it is only possible to detect it in faults or associated with alkaline volcanism (Barnolas \& Pujalte, 2004: 233-239; Pujalte et al. 2004). The Oviedo Basin constitutes a series of strata also formed during Mesozoic and Paleogene times. This area shares many characteristics with the previous zone.

Each of the two primary divisions is associated with specific lithologies used by Palaeolithic populations as raw materials, as already suggested by previous research (Bernaldo de Quirós \& Cabrera 1996; González Sainz 1991; Straus 1996). Quartzite is, in general terms, associated with the Iberian massif because of the existence in this area of wide siliciclastic outcrops, occasionally deformed and/or metamorphic (Bastida 1982). It is also important to mention the presence of quartzite blocks in the numerous conglomerate strata formed during the Carboniferous, especially in the eastern half of the Cantabrian Zone (Fernández et al. 2004; Prieto et al. 2021). In contrast, flint is mainly associated with the Basque-Cantabrian Basin and the Oviedo Basin (Tarriño et al. 2015). The latter two were created during the Mesozoic and the Paleogene under marine and partially palustrinelacustrine sedimentary conditions which favour the formation of chemical siliceous sedimentary rocks such as flint (Tarriño et al. 2015). Still, it should be noted that flint, chert or other microcrystalline rocks such as radiolarite are also represented in the older strata of the Cantabrian Zone and were recently systematised by Herrero-Alonso (2018: chapter 6). As will be explored in more detail later, and thanks to the research funded by Andoni Tarriño, today, more than 30 flint outcrops formations were discovered in the area.

\section{Methods}

To carry out this research, a database was created with the information available in the literature. Palaeolithic sites where raw materials were described and quantified using basic rock descriptions were selected. Most of the descriptions, according to the references, were made using de visu criteria and hand magnifiers. The level of detail of these descriptions is low, although it should be enough for a basic lithological identification. It is important to remark that some of the data used derived from excavations and research projects that are older than 50 years. This could then promote a biased overview because of the different excavation methodologies and criteria to select the lithics and the artefacts described. The most frequent and widely representative raw materials of the whole region were highlighted and quantified individually (flint, quartzite, quartz and dolerite). Because of their scarcity, other raw materials such as lutite, radiolarite, sandstone or limestone were not included on specific categories and they were grouped on the broader category "Other Raw Material". Moreover, they were individually used to contextualise the data. As already mentioned by several authors (e.g., Howard 2005; Prieto et al. 2019a; Skolnick 1965), the limits between which quartzite and sandstone can be distinguished are not clear, especially when they are analysed without petrographic microscopy. In which case, quartzite and sandstone could have 
been mixed in some of the analysed archaeological contexts. It is also relevant to mention that dolerite was referred to in many publications as ophite (field name for mafic igneous rocks) or diabase. The number of sites comes to 30, and they comprise a total of 210 archaeological levels (Supplementary File 1). The selection of the sites and archaeological levels was based on data available at the time this research was designed, the geographic representation, the quality of the information, and the precision of the data. Also, it was important to ensure that sites in the entire geographical area under analysis were represented. In order to systematise the results, we converted the data shown in the bibliography into percentages for each archaeological level. The latter is the basic unit of analysis used in this research. They have been organised following the techno-typological classification of their lithic industries given by the authors first. To standardise the data, we used the classical seriation of lithic technocomplexes in Western Europe, that is Mousterian $(\mathrm{N}=90)$, Aurignacian $(\mathrm{N}=32)$, Gravettian $(\mathrm{N}=13)$, Solutrean $(\mathrm{N}=45)$ and Magdalenian $(\mathrm{N}=30)$. This organisation allowed us to understand the general chronological tendencies. We are aware of the chronological inequality of the data, especially because of the high number of levels categorised as Mousterian and the small quantity of Gravettian levels. If more than one archaeological level is assigned to a specific techno-complex on a site, the average from the different levels was used. The number of techno-complexes displayed at different sites is 55. Finally, and to understand a general and geographic overview, the average between the different technocomplexes on each site was calculated.

The database was analysed using a Geographic Information System. The program used was ArcGIS 10.2 and the base map was created by merging (merge tool) the DEM 200 maps obtained from the Geographic Institute of Spain IGN (IGN, 2020). Different options of representation, such as pie charts, were used to display the information collected. In addition, a Kernel density tool was used to analyse the geographic representation of better-represented raw materials. The kernel search radius is $60 \mathrm{~km}$ (the widest area without any archaeological site).

\section{Results}

Supplementary File 1 shows the information collected to carry out this research. Figure 2 displays all the analysed archaeological sites in their geographic location. They are well distributed in the territory, except for the western area, where we do not find a similar quantity of Palaeolithic archaeological sites to allow comparisons with other parts of the territory. In the area of study, the greatest distance without any archaeological site is less than $60 \mathrm{~km}$ (between El Mirón and Arlanpe). There is a tendency, derived from historiographical issues, of an accumulation of sites around the Bay of Santander. It should be stressed that there are more sites in the Basque Country with raw material studies, but they were not included in the numerical analysis because of the redundancy of the data and the absence of information about raw materials other than flint. Moreover, they are included in the data discussion.

This general data is explored using large-scale geological information. Figure 3 shows the raw material percentage at each site. First, it can be noted that none of the selected sites has just one raw material, and the lithic assemblages were formed by diverse types of rock. It is also remarkable that most of these sites have one main raw material (with percentages higher than 50\%) and some other secondary raw material (around 20\%). In some cases, there are also trace raw materials (specific rocks with smaller percentages than $5 \%$ ). The first category is only associated with flint and quartzite. Secondary raw materials are also associated with the same two rocks and, only in a few cases, with quartz or "other raw materials”. 


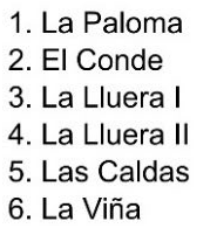

1. La Paloma

3. La Lluera I

4. La Lluera II

6. La Viña

13. El Esquilleu
14. El Arteu
15. Panes II
16. Hornos de la Peña
17. El Castillo
18. La Flecha

19. Covalejos

20. El Pendo

21. El Juyo

22. El Ruso I

23. Morín

24. Rascaño
25. El Mirón

26. Arlanpe

27. Axlor

28. Lezetxiki

29. Amalda

30. Aitzbitarte III

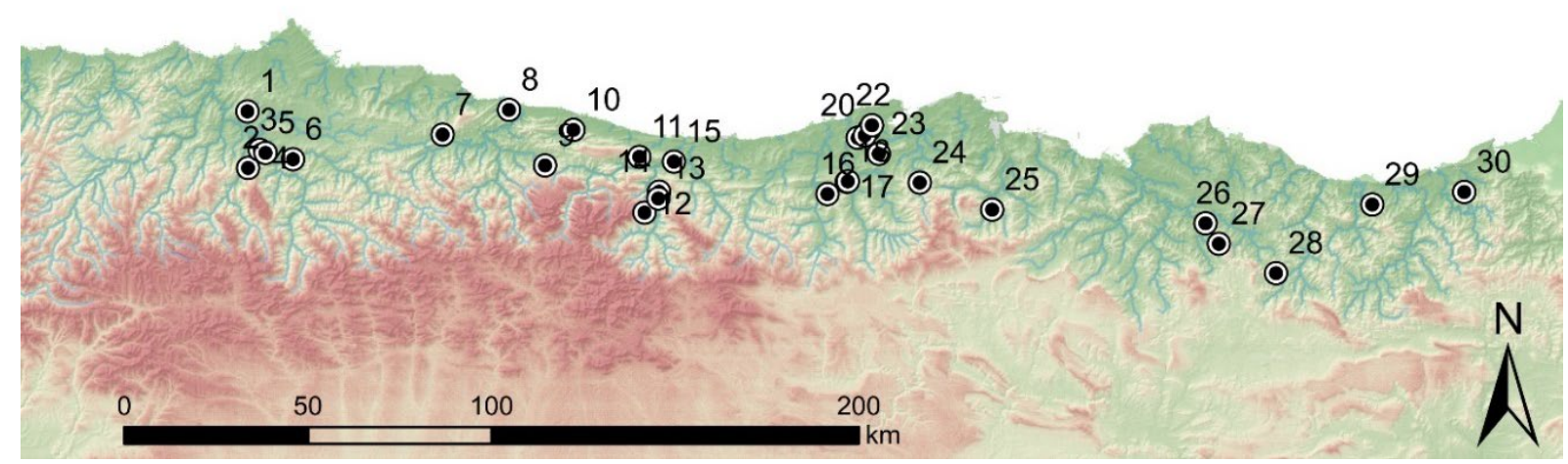

Figure 2. Archaeological sites included in this research.

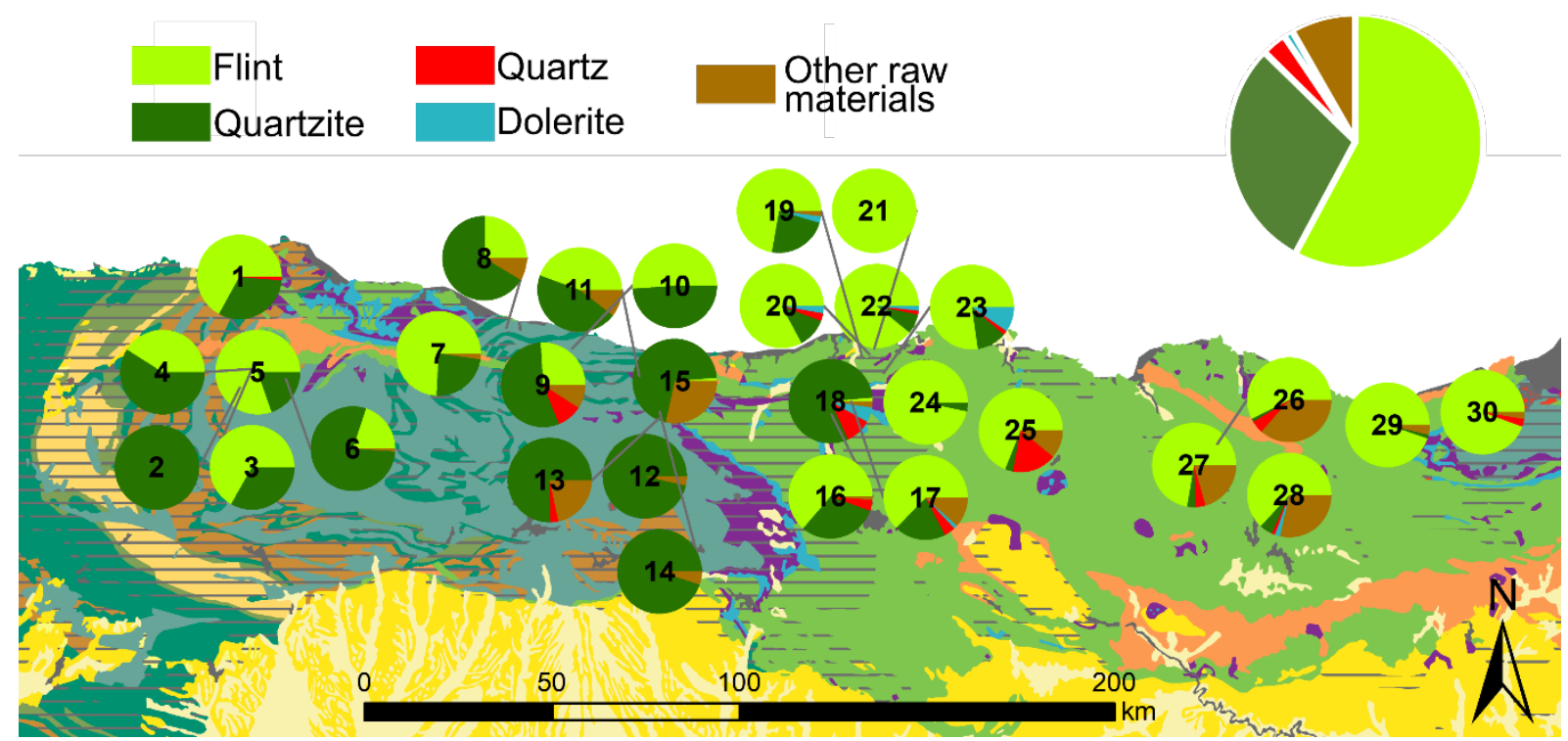

Figure 3. Raw material distribution at each archaeological site using pie charts. The general pie chart in the upper right represents the mean distribution of raw material in the selected sites. Main chrono-lithological strata in the Cantabrian Region are displayed, based on a 1:1.000.000 geological map (Álvaro et al. 1994). The colour of each stratum is the same as in Figure 1. The numbers of the different archaeological sites are also the same as in Figure 2.

Clear geographic zoning can be observed in the most representative raw material in the lithic assemblages at the selected sites. Flint is associated with the eastern part of the Cantabrian Region, while quartzite is better represented in the western area. Flint is also represented in the western zone of the Cantabrian Region, although generally as a secondary raw material, chiefly in the Oviedo basin. In contrast, quartzite is rare in the eastern part, and is only represented as a trace material to the east of the Bay of Santander. Figure 4 shows two different maps representing raw material Kernel density for flint and quartzite. They reinforce this geographic association. All these data demonstrate a clear connection between lithic raw material data and geological information. Quartzite is associated with the Iberian Massif, represented by Palaeozoic and Precambrian materials. The core area of quartzitic rock is in the Cares, Deva and Sella Valleys. Flint is more closely associated with Mesozoic and Cenozoic strata and represented mostly around the Bay of Santander and in the Basque 
Country. In the latter area, flint is the dominant raw material at many other sites, not considered in this work, e.g., Labeko Koba, Antoliñako Koba, and Ametzagaina (Aguirre 2012; Arrizabalaga 2000; Arrizabalaga et al. 2014a).
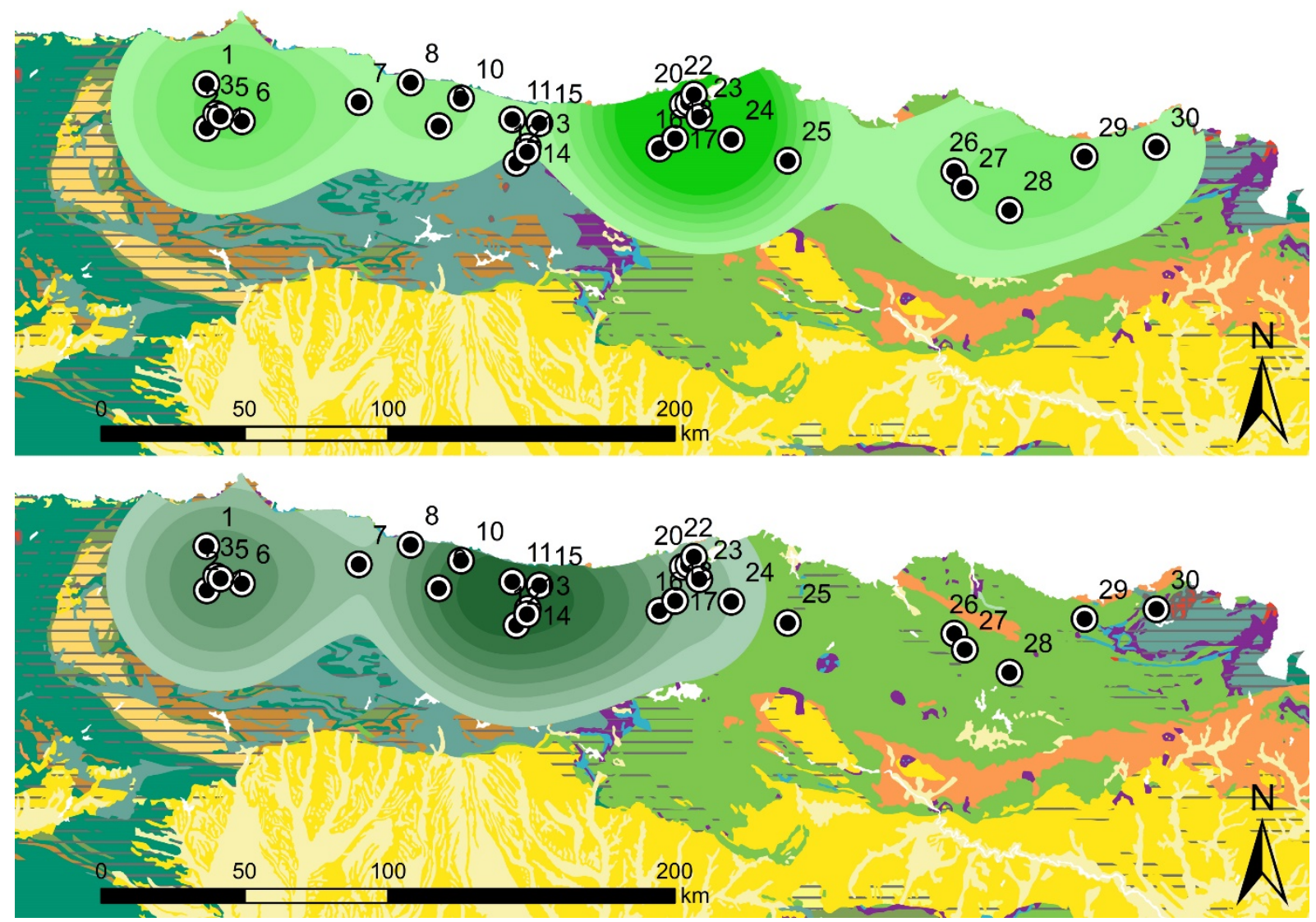

Figure 4. Kernel density of flint (above) and quartzite (below). Intense green on each map displays a higher density of flint or quartzite. Main chrono-lithological strata in the Cantabrian Region are displayed, based on a 1:1.000.000 geological map (Álvaro et al. 1994). Lithology colours are the same as in Figure 1 . The numbers of the different archaeological sites are also the same as in Figure 2.

As already suggested, quartz and dolerite are constrained to small occurrences in specific sites without a clear relationship with the main geological units. Quartz and its multiple varieties described by archaeologists (rock crystal or hyaline quartz for automorphic quartz, polycrystalline quartz, milky quartz or grey quartz for xenomorphic quartz) appear in different geological contexts (de Lombera-Hermida 2008). It is well represented at such sites as El Mirón (17\%), La Flecha (10\%) and Sopeña (8\%). In other sites the quantity of this raw material is much more limited. Dolerite, a greenish basaltic rock, is only represented in percentages higher than $5 \%$ in the sites of Cueva Morín and La Flecha. As stated above, the category labelled as 'other raw materials' is a mixed category, although the best represented raw materials are sandstones and lutites. The latter is also well represented in the Basque sites.

Having explained the data from a general and geographic perspective, this is now presented with the chrono-cultural information. There is a general tendency towards a clear and gradual decrease in the presence of quartzite and other raw materials and an increase in flint in the lithic assemblages (Figure 5). This trend points towards raw material standardisation, with flint becoming the most represented resource for lithic production for Magdalenian populations. The increasing trend is relatively gradual from the Mousterian to the Magdalenian, although during the Solutrean, the percentage of flint is similar or even 
smaller than during the Gravettian. In the Magdalenian, flint percentages increase to values higher than $75 \%$. Conversely, there is a clear decrease in the percentage of quartzites in this succession of different periods, although in the Solutrean there is a slight increase in the quantity of this raw material. It is also remarkable that quartz was better represented during the Gravettian than in previous and, especially, in later periods, when this raw material is rare. Other raw materials, like dolerite, are present in the preceding periods, and more generally although their percentages gradually decline from the Mousterian to the Magdalenian.

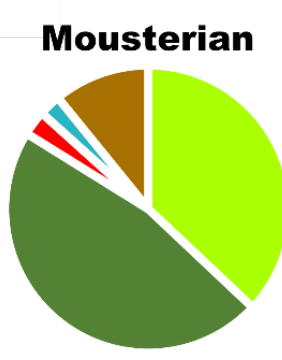

Flint

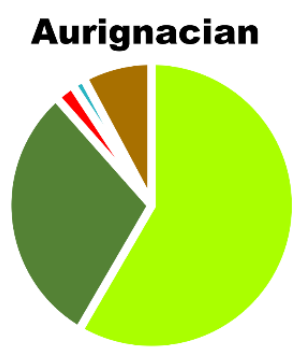

Quartzite

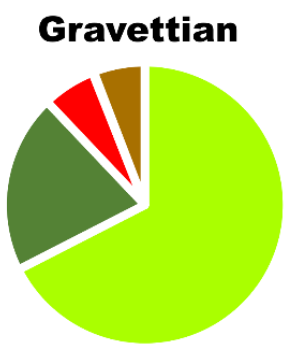

Dolerite

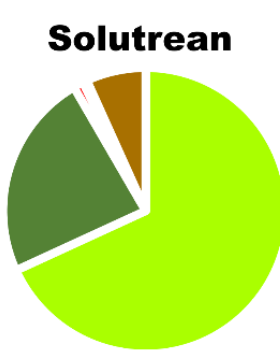

Magdalenian

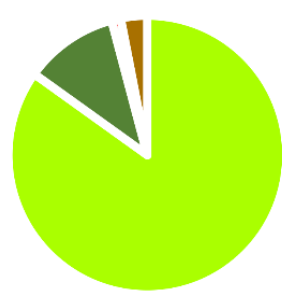

Other raw

Figure 5. Pie charts representing percentages of raw material grouped by techno-complexes.

Having outlined the general chronological trends, the embedded geographic differences in each techno-complex are described. Figure 6 shows the distribution of raw material during the Mousterian, displaying the high variability of raw material in the archaeological sites.

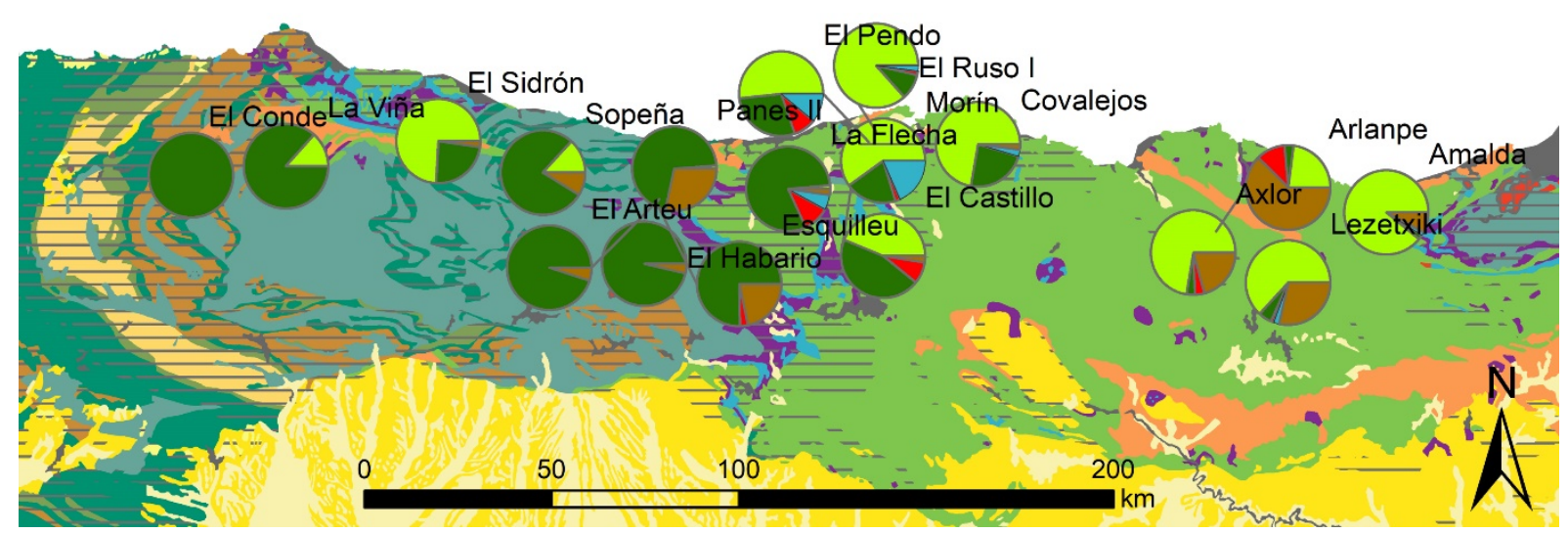

Figure 6. Raw material distribution at each archaeological site during the Mousterian using pie charts. Main chrono-lithological strata in the Cantabrian Region are displayed, based on a 1:1.000.000 geological map (Álvaro et al. 1994). Lithology colours are the same as for Figure 1. Pie chart colours are also the same as in Figure 3.

Quartzite is geographically associated with the western part, with percentages greater than $75 \%$. Only in the lithic assemblage of El Sidrón, associated with a single event related to the human fossils of the cave, flint is the best represented raw material (Santamaría et al. 2010; 2011). Conversely, in the eastern part, flint is the main raw material in the archaeological assemblages. Except for the case of Arlanpe (Rios-Garaizar 2013), a site with short occupations characterised by a small number of artefacts which are mainly made on lutite, flint is the main raw material, with percentages larger than $60 \%$. At the sites around the Bay of Santander, flint is also the main raw material, although quartzite is generally well represented as a secondary or even a primary raw material. It is interesting to observe how at those sites around the Bay of Santander, flint is the best represented raw material, whilst in the area around Puente Viesgo quartzite is better represented than flint, as shown by La 
Flecha (Castanedo 2001) and El Castillo (Cabrera 1984: chapters V to X). During the Middle Palaeolithic, the use of raw materials other than flint and quartzite is also well documented. In the latter zones, dolerite and also quartz, are frequent, especially at Morín (González Echegaray \& Freeman 1978: 217-252), El Pendo (González Echegaray 1980; Freeman 1980) and La Flecha. At El Castillo, quartz is well represented, as in La Flecha and El Pendo. In the western part, the use of quartz is limited and dolerite is insignificant. In this area, the most recurrent secondary raw material is sandstone, followed by lutite and limestone. In the eastern area, the category of other raw materials is also related to these raw materials, although lutite is more frequent.

In the first half of the Upper Palaeolithic (Aurignacian and Gravettian), a clear change is observed in the raw material distribution, as shown by Figure 5 and displayed geographically in Figure 7a. This trend is observable at sites in the eastern part of the Cantabrian Region, where the quantity of flint is, in general terms, greater than in other places. In the analysed layers at Aitzbitarte III, flint is the best represented raw material, and other kinds of rocks are rare. This is also observable in the Aurignacian levels at Labeko Koba, not included in our database (Arrizabalaga 2000). In the central part of the Cantabrian Region, flint is better represented than in the previous period, although other raw materials are still represented. The quantity of quartzite is smaller, but still higher than 5\% at every analysed site. In the western part, while quartzite is still the best-represented raw material, flint percentages increase from the previous periods. This is easy to detect in sites such as La Viña and Sopeña, where the proportion of flint increases by more than 10\% (Pinto-Llona et al. 2009; 2012; Santamaría 2012: chapter 6).

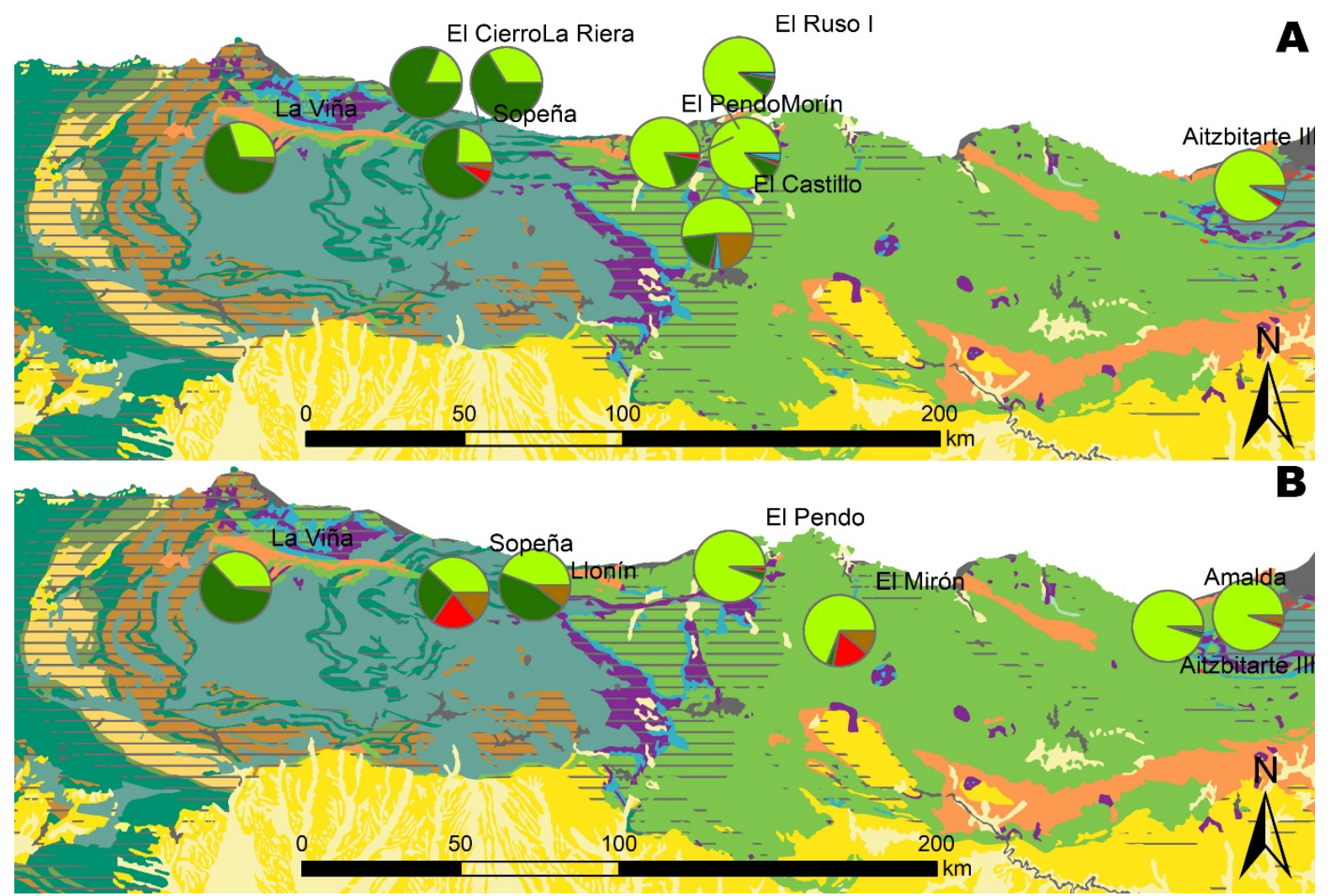

Figure 7. Raw material distribution at each archaeological site during the Aurignacian (above) and the Gravettian (below) using pie charts. Main chrono-lithological strata in the Cantabrian Region are displayed, based on a 1:1.000.000 geological map (Álvaro et al. 1994). Lithology colours are the same as for Figure 1 . Pie chart colours are the same as in Figure 3. 
During the Gravettian, although the analysis is hampered by the small number of sites, the tendency already suggested during the Aurignacian is reinforced (Figure $7 \mathrm{~b}$ ). The quantity of flint in the eastern sites is still high, and, in addition to the analysed sites of Aitzbitarte III and Amalda, the pattern is also observable in Bolinkoba (Iriarte-Chiapusso et al. 2015), Ametzagaina (Calvo et al. 2013), Amalda, Usategi (Calvo, 2019: 159-164) and Antoliñako Koba (Tarriño 2006: 136-141; Aguirre 2012). At El Mirón (González Morales \& Straus 2012) and especially at El Pendo (González Echegaray 1980), flint clearly dominates the raw material distribution, and quartzite becomes a trace material instead of a secondary one. Finally, in the western area, the percentages of flint in the selected assemblages increase, displaying similar frequencies as quartzites. La Viña, Llonín, Cueto de la Mina (Martínez \& de la Rasilla 2012), but also Coimbre (Álvarez-Alonso et al. 2017) and Sopeña (Pinto-Llona et al. 2012) are indicative of this trend. During this period, the presence of quartz in sites such as La Viña, Sopeña and El Mirón is also noteworthy. The presence of the latter is not geographically zoned.

During the Solutrean, this trend stops, as observed in the general data shown in Figure 5. This is because of the small increase of quartzite in lithic collections as other authors have already argued (de la Rasilla \& Fernández de la Vega 2014; Schmidt 2013; Straus 1983: 125 127; 2001; 2012). Figure 8a identifies this situation in the central and western part of the Cantabrian Region, where, in sites such as Hornos de la Peña, El Pendo, La Riera, El Cierro and La Lluera, quartzite percentages are high. There is also a clear decrease in quartz which makes this lithic resource almost disappear from the analysed sites. In the eastern zone, flint is the main and almost only raw material used by Upper Palaeolithic populations, seen not only at Amalda, but also at Antoliñako Koba (Aguirre 2003; Tarriño 2006: 136-144). The presence and the higher percentages of raw materials other than flint in the site of Arlanpe should be understood as a result of a secondary accumulation of some artefacts, rather than a clear representation of the raw material in this assemblage.

Finally, during the Magdalenian, the final result of the trend explained above is seen and flint becomes the main and most important raw material in the Cantabrian Region. Nevertheless, there are again clear geographic differences in the area of study and some observations must be made (Figure 8b). In the eastern zone, flint is still the only raw material used by Palaeolithic people. At Arlanpe, the site is not sufficiently represented to understand its raw material variability. Instead, Aitzbitarte III, but also such other sites as Antoliñako Koba (Tarriño 2006: 136-144), Santimamiñe (Tarriño 2011b) or Urtiaga (Fontes 2016) confirm the importance of flint in this area. In the central part of the Cantabrian Region, flint is the best represented raw material with percentages higher than $80 \%$ at every site (generally greater than 95\%). Quartzite, also other raw materials, must be considered trace materials with quantities below 5\%. Finally, in the western area, despite flint becoming the main raw material at the analysed sites, quartzite percentages are still significant (higher than $20 \%$ at every analysed site), confirming the trend but also indicating persistence in the use of this raw material in these western areas.

\section{Discussion}

\section{1. New geoarchaeological methods, new perspectives}

As stated in the introduction, the geoarchaeological characterisation of raw material (particularly flint) using textural, mineral and geochemical analysis started in this region in the late 1990s, mainly based on research by A. Tarriño (Tarriño 2006; Tarriño \& Terradas 2013). This work was based on the geoarchaeological characterisation of flint in its source areas, the bedrock, and of course, in the archaeological lithic assemblages. These studies changed previous acquisition models mainly based on local or semi-local procurement of flint 
(Sarabia 1999; 2000). The new model, synthesised by Tarriño et al. (2015), revealed more complex flint procurement strategies during the Upper Palaeolithic in which local, regional and "tracer" flint types were obtained from different places in the Cantabrian Region. It proposed that in the Upper Palaeolithic, raw material was procured up to $200 \mathrm{~km}$ away from the site where the artefacts were discarded.

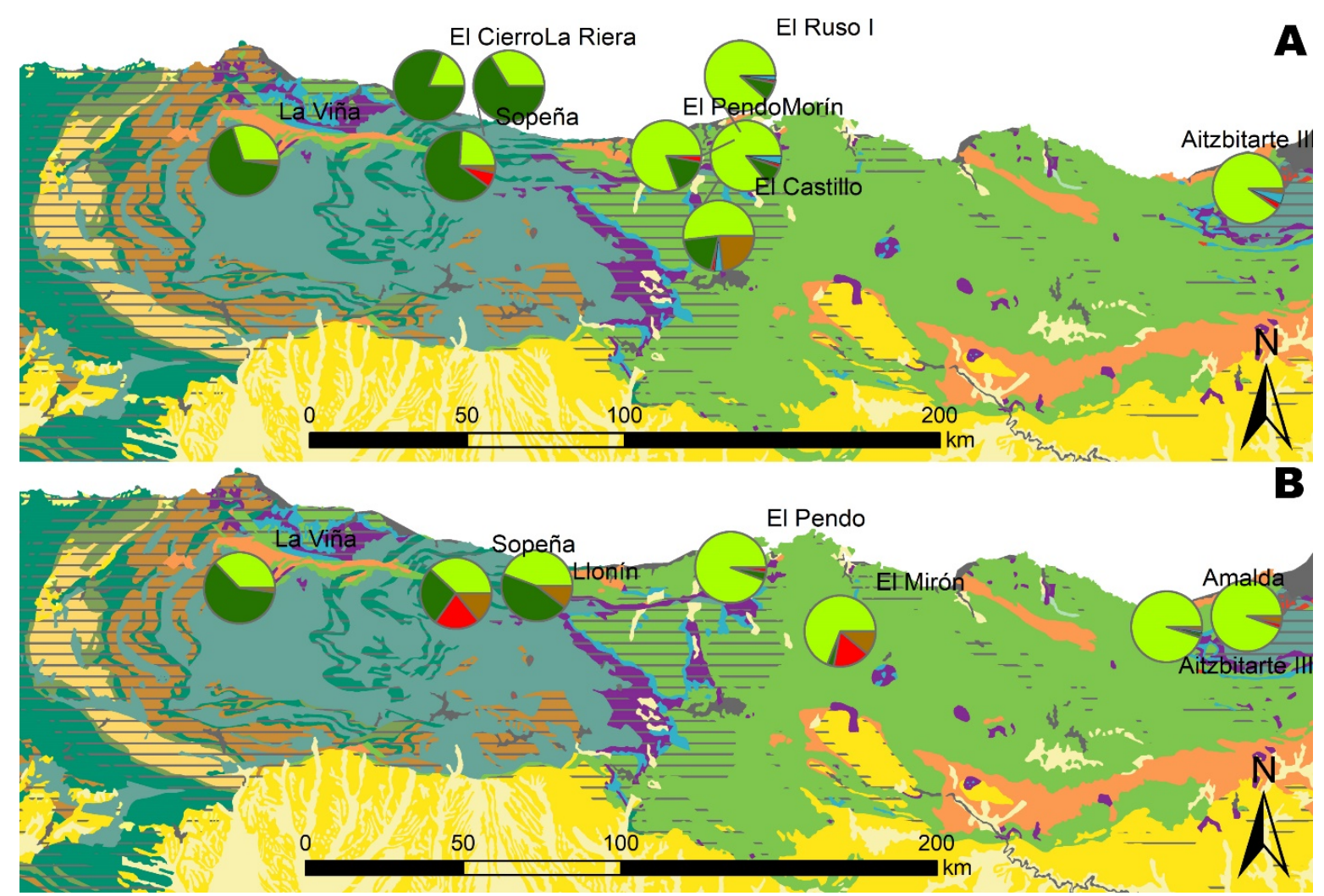

Figure 8. Raw material distribution at each archaeological site during the Solutrean (above) and the Magdalenian (below) using pie charts. Main chrono-lithological strata in the Cantabrian Region are displayed, based on a 1:1.000.000 geological map (Álvaro et al. 1994). Lithology colours are the same as for Figure 1 . Pie chart colours are also the same as in Figure 3.

The application of these geoarchaeological methods is changing the perspectives of flint procurement in the Cantabrian Region. The first studies, mainly focused on the eastern part of the Cantabrian Region, were particularly based on geoarchaeological characterisation of the source area (i.e., Tarriño \& Aguirre 1997; Tarriño et al. 1998; Tarriño 2000). The longdistance imports were proposed as one of the main conclusions from those studies. The establishment of the methodology, the description of the most important flint outcrops in the eastern part of the Cantabrian Region, the identification of those flint types and others from the northern side of the Pyrenees at the archaeological sites in the Basque Country, and the conclusion mentioned above were highlighted in the Tarriño's Ph.D. thesis (Tarriño 2001), published five years later (Tarriño 2006). This milestone contributed to the expansion of this type of study during the following years. Other Upper Palaeolithic sites in addition to Labeko Koba and Antoliñako Koba in the eastern part of Cantabrian Region, such as Aitzbitarte III (Tarriño 2011a) and Santimamiñe (Tarriño 2011b), were analysed. The results highlighted previous ideas, and also reinforced the understanding of the eastern part of the Cantabrian Region as a preferential corridor between the Iberian Peninsula and the rest of the European continent (Arrizabalaga 1998; 2007; Arrizabalaga et al. 2016).

The characterisation of new outcrops in other areas than the eastern part of the Cantabrian Region started after that milestone. Today, more than 30 types of flints are characterised and 
associated with different geographical origins, mainly in connection with the BasqueCantabrian Basin, but also the Oviedo basin or Palaeozoic domains (Duarte et al. 2016; Elorrieta 2016: 63-94; Fuertes-Prieto et al. 2016; Herrero-Alonso 2018:177-380; HerreroAlonso et al. 2016; 2020; Rissetto 2009: 83-144, App. A and App. B; Santamaría 2012: 238253; Tarriño et al. 2013; 2015; 2016). This corpus allowed for the characterisation of the most representative flint types in the Cantabrian Region, and opened up the possibility of understanding complex procurement mechanisms and the determination of catchment areas for different Middle and, especially, Upper Palaeolithic sites. Research at sites such as Las Caldas (Corchón et al. 2009), La Viña (Santamaría 2012: 254-1177), Coimbre (ÁlvarezAlonso et al. 2017; Tarriño \& Elorrieta 2017), El Mirón, El Horno, El Perro, La Fragua (Rissetto 2009: 195-241; Fontes 2016; Fontes et al. 2018), Ametzagaina (Calvo et al. 2013), Aitzbitarte III, Amalda, Bolinkoba, Usategi (Calvo 2019: chapters 18 to 24; Calvo and Arrizabalaga 2020) and El Cuco (Rios-Garaizar 2020) has provided information about flint circulation in the Cantabrian Region. This information was used to determine the distribution ranges of some flint types, emphasising the importance of Kurtzia Flysch, Urbasa and Treviño flints as "tracer" types (all outcrops in the eastern part of the Cantabrian Region) and the establishment of new regional (e.g., Alba Formation Radiolarite, Gaintxurizketa Flysch flint, Monte Picota flint and Piloña flint) or local flint varieties (e.g., Vegamián Formation chert, Pendueles chert and Infiesto flint) (Tarriño et al. 2015). Some of these studies also incorporated the techno-typological analysis of lithic assemblages, providing information about complex and varied management strategies applied by Palaeolithic societies for each type of flint. In the eastern and central part of the Cantabrian Region, sites such as Antoliñako Koba, Baltzola, Kukuma, (García-Rojas 2014: 232-462), Aitzbitarte III, Amalda, Bolinkoba, Usategi (Calvo 2019: chapters 18 to 24; Calvo \& Arrizabalaga 2020), Ametzagaina (Arrizabalaga et al. 2014a; Calvo et al. 2013), Urtiaga, El Mirón (Fontes 2016; Fontes et al. 2018), and el Cuco (Rios-Garaizar 2020) have also contributed data about this complexity. These studies are mainly based on how, and in which format, each variety of flint was incorporated into each archaeological context.

The last perspective the geoarchaeological characterisation of flint opened up has been related to the development or the application of other methodologies, especially those associated with Geographic Information Systems. They have focused on two aspects related to flint procurement strategies. The first aimed to determine the exact movements of prehistoric societies (Rissetto 2012). This research suggests that rivers and the main valleys, together with coastal corridors, were the most commonly used routes for flint procurement. The second is aimed at understanding human mobility using a more flexible measurement, Cost Units, to compare raw material procurement together with the quantity and the format of flints. The latter is used to understand the social and economic territories articulated by Palaeolithic populations (García-Rojas et al. 2017; Prieto et al. 2016; Sánchez et al. 2016). The results show high-complexity flint procurement strategies related with recurrent trips for raw material acquisition from a determined site to the main flint outcrop, and also the abandonment at the site of other flint types as the result of previous recurrent trips to less accessible areas from the site, and longer trips. These are related more with permanent mobility over wider areas (Prieto et al. 2016). They also reinforce ideas proposed by other proxies of analysis related with aggregation sites during the Upper Palaeolithic, as depicted by Sánchez et al. (2016), in places such as Santimamiñe and Isturitz where the variety and quantity of non-accessible flints are greater than in other non-aggregation sites. In general terms, these distant-source flint types are made into complex artefacts, whilst complete reduction processes are mostly related with more accessible flint outcrops (García-Rojas et al. 2017). 


\section{2. Old data, new perspectives, forthcoming interpretations and narratives}

This last section reflects on the general raw material framework depicted in the results section and the new perspectives opened up by the application of the geoarchaeological methodology developed to understand flint procurement. Doing so, we can understand the state of play regarding raw material distribution in the Cantabrian Region, and propose future strategies to unveil new narratives and interpretations in economic and social territories.

The current research points to interconnected axes governing raw material distribution in the Cantabrian Region. The first axis is geographical and shows that raw material distribution is highly dependent on the geological strata. The zoning of the latter contributes to the distribution of the main raw materials. Flint is mainly associated with the eastern part of the Cantabrian Region, related with the Basque-Cantabrian Basin, the major flint-supplying area (Tarriño et al. 2015). The procurement of flint in the western part was mainly achieved in the Oviedo Basin, a Mesozoic and Cenozoic area created in similar conditions to the BasqueCantabrian basin. Moreover, the importance of other micro-or crypto-crystalline rocks such as radiolarites or black cherts in the western area must be highlighted, although, in this case they are associated with the Palaeozoic Iberian Massif. Quartzites are better represented in the western area because of their massive presence in older strata, mainly Carboniferous series of conglomerates, but also Devonian, Silurian, Ordovician, Cambrian and Precambrian outcrops. Other raw materials such as quartz, lutites or sandstones are not so clearly related with this geographical zoning. These data support the idea that lithic raw material procurement during the Palaeolithic mainly involved relatively local or regional rocks.

The second axis is the chronological one, which shows a general tendency towards standardisation in flint procurement by Palaeolithic societies, resulting in the substitution of quartzites, quartz, dolerite, sandstones and lutites by flint in a chronological trend, from the older to the more recent periods. The relationship of this axis with the geographical one is clear, as demonstrated by the faster and more intense substitution of raw material at sites situated in the Mesozoic and Cenozoic domains, rather than in the Palaeozoic or Precambrian ones. This replacement of raw material suggests two explanations that may, or may not be, related. The first one is connected with direct procurement from distant flint outcrops in a general West to East direction. The second is related to the increase of selective procurement strategies in areas in which flint is scarcer, and more dispersed relative to other raw materials, mainly quartzite.

Similar perspectives were also highlighted in previous works addressing the duality of raw material representation (flint and quartzite) in the Cantabrian Region during the Palaeolithic (e.g., Bernaldo de Quirós \& Cabrera 1996; González Sainz 1991; Straus 1996). The East-West gradation in the flint-quartzite representation was already acknowledged, as the general, but partial, substitutions of quartzites from the Middle Palaeolithic to the later periods of the Upper Palaeolithic. This research also emphasised how the quality of the different raw materials and its accessibility in particular areas of the Cantabrian Region mainly (González Sainz 1991) or partially (Bernaldo de Quirós \& Cabrera 1996; Straus 1996) determine techno-typological variability observed in the Cantabrian Region. This is especially relevant for specific (and sometimes iconic) retouched artefacts and also the implication in understanding determined chronocultural changes (see also Baena Preysler et al. 2019).

The information provided by the two axes, geographical and chronological, together with the perspectives of the new geoarchaeological techniques, converge in a mixed and progressively more complex model of raw material procurement. This is based on a successively more exhaustive regional procurement of raw material, superimposed on a progressively wider and a more intensive network that supplied a larger quantity of flints. This model, mainly based on an up-down approach, proposes a holistic and wide framework 
that needs to be filled with new and more precise research based on a bottom-up perspective. To do so, it is necessary to continue the dynamics of the last twenty years, that is, to characterise new flint outcrops and also Palaeozoic silicifications (Herrero-Alonso 2018: 177380), identify flint in archaeological assemblages (Tarriño \& Elorrieta 2017), relate the flint types with other proxies of analysis (techno-typology, metric characterisation, use-wear, etc.) (Arrizabalaga et al. 2014b; Calvo 2019; García-Rojas 2014), and understand their geographic relationship with other sites and the outcrops (Prieto et al. 2016).

It is also necessary to understand how the bias derived from the absence of geoarchaeological characterisation of raw materials other than flint is modifying, geographically and chronologically, our paradigms on raw material economy in the Cantabrian Region, as has been depicted by the general model proposed. Additionally, and as reflected in current historiography, this bias also affects the interpretation of our data. Still, the geographical imbalance in research into the characterisation of flint in the different sectors of the Cantabrian Region is also influencing our perspectives of the raw material economy of the area. This bias firstly affects this overview through a clear geographical component, because the distribution of geological strata promotes the absence of information in the western part of the Cantabrian Region where quartzite is, in general, the best-represented raw material. Secondly, this bias modifies the chronological overview, discriminating raw material research in favour of later Upper Palaeolithic periods, when flint is quantitatively predominant. Finally, we also have a distorted overview of raw material procurement because the unbalanced research into different raw materials promotes an overinterpretation of longdistance procurements, and therefore promotes historical narratives mainly based on human mobility that hide many quotidian activities and the daily life of prehistoric people. To solve these issues, it is necessary to continue researching raw materials other than flint in the area, such as quartzite (Prieto et al. 2019a; 2020; 2021), lutites (Arrizabalaga \& Tarriño 2010; Fernández-Eraso et al. 2017), or quartz (de Lombera-Hermida \& Rodríguez-Rellán 2016), but also to characterise and enlarge the procurement studies of flint in the Central and Western parts of the Cantabrian Region (e.g., Herrero-Alonso 2018; Herrero-Alonso et al. 2020).

In combination, all these data will allow us to delimit and understand each time slice, the hidden dynamics, and the differences in raw material procurement between and within regions. These new perspectives should also change our interpretation of lithic procurement by not only looking at the distances but the economic and social dynamics hidden behind raw material procurement. Therefore, this will turn the procurement of raw material from the mobility of people and/or objects to other narratives more closely related to the daily life of people such as territorial use, management of lithic resources, search and selection of raw material and acquisition, as well as on the path and not only on the outcrop.

Several pieces of research in Europe (e.g., Daffara et al. 2019, Mathias et al. 2020; Prieto et al. 2019b), Asia (e.g., Groucutt et al. 2017) and Africa (e.g., McHenry \& de la Torre. 2018; Soto et al. 2020) acknowledge the value of the so-call "alternative" raw material than flint during the Palaeolithic. In each of these different areas, the representation and importance of the "alternative raw materials" compared with flint differ from places and periods due to the geology of each area, the dispersion, the accessibility, the natural formats and the quality of their potential raw material, but also due to the different human adaptive or cultural behaviours. The understanding of these factors can only be approached, first, through the identification on the assemblages of these raw materials and the validation of these rocks as potential artefacts (Knutsson 2014) and, second, through characterisation of these rocks using geoarchaeological protocols. In this way, we can understand the specific economic and social organisation around quartzites and other "alternative" raw materials (Daffara et al. 2019; Groucutt et al. 2017; McHenry \& de la Torre 2018; Prieto et al. 2019b; Soto et al. 2020). 


\section{Conclusions}

The procurement of lithic raw materials in the Cantabrian Region during the Palaeolithic was highly conditioned by its local availability. The region is basically divided into two geological domains: the western area (Asturias and western half of Cantabria) and the eastern area (eastern half of Cantabria and the Basque Country). In the western domain, flint outcrops are rare, less accessible or present non-desirable natural formats (Herrero-Alonso, 2018) and quartzite was the main raw material used by Palaeolithic populations. In the eastern domain, flint is more common and quartzite is not easily available. The historiography of the discipline has resulted in more rapid progress being made in characterising flint than other lithic resources, especially quartzite. Thus, until the doctoral thesis of one of the present authors (Prieto 2018), the little that was known of this subject referred to flint, particularly its Basque outcrops. This has caused asymmetry and an imbalance in research that we are aiming to solve (Prieto et al. 2019a; 2020; 2021).

As the present paper has described, the overall view has observed the preference of Palaeolithic hunter-gatherers in the Cantabrian Region towards the use of flint to make their tool kits. With some chronological fluctuations, this preference manifested itself gradually from the Mousterian to the late Magdalenian. It is a trend that can be detected already in Mousterian sites in the eastern area, and spread from east to west in a double geographic and diachronic gradient, and reached the western end of the region in the Magdalenian. It should be noted that, despite this replacement, quartzite and other raw materials continued to be important in quantitative and qualitative terms. A more detailed observation however, can detect interesting information with regards to the different roles that these raw materials played in specific times, geographic settings and human contexts (Prieto et al. 2019a; 2020; 2021). This detailed geoarchaeological approach can explain the presence of alternative raw materials to flint, either because of their good quality, their accessibility or natural format. It also allows a contextualisation of the reasons why prehistoric groups did not select certain flint varieties. Although few flint varieties in the Cantabrian Region still require characterisation and the flint at other archaeological sites in the region need to be studied, it is important to advance the study of quartzite, lutite and quartz, because balancing the state of knowledge of different raw material promotes a better understanding of the technological and palaeoeconomic dynamics that governed the behaviour of the societies that used those lithic resources.

This will enable the characterisation of more potential sources of lithic raw materials in regions where quartzite is important and, in this way, determine the procurement and management strategies in other geographic areas. It will also help us to understand the social and economic territories in periods for which this information is currently lacking. Finally, the geoarchaeological study of other raw materials and geological formations will underpin narratives more closely linked with the daily life of prehistoric populations and modify the dominant paradigm that favours conclusions related to the long-distance mobility of objects and people.

\section{Acknowledgements}

This research was partially supported by the project HAR2017-82483-C3-1-P financed by the Spanish Ministry of Science and the Consolidated Research Group in Prehistory of the Basque Country University (IT- 1223-19). A. Prieto and A. Arrizabalaga are part of this project and both are members of the research group. A. Prieto is also a collaborator in the project HAR2016-76760-C3-2-P funded by the Spanish Ministry of Science and FEDER funds. A. Prieto is funded by the Education Department of the Government of the Basque Country through a postdoctoral fellowship (POS_2018_1_0021). The authors thank the 
anonymous reviewers and layout editors of JLS (Xavier Mangado, Cynthia González and Stephanie Piper) for their help improving the original manuscript.

\section{Data accessibility statement}

The authors confirm that the data supporting the findings of this study are available within the article and its supplementary files.

\section{List of supplementary files}

Supplementary file 1

"PRIETO - supplementary file 1 - SF_Raw material distributions.xls"

Raw material distribution on each archaeological level addressed in this research.

\section{References}

Aguirre, M. 2003, El yacimiento de Antoliñako koba (Gautegiz-Arteaga, Bizkaia): secuencia estratigráfica y dinámica industrial. Avance de las campañas de excavación 1995-2000. Illunzar, 4: 13-38. (in Spanish) ("The site of Antoliñako Koba (Gautegiz-Arteaga): stratigraphy and lithic dynamics: initial results from the excavation 1995-2000") URL: http://www.arkeoagiri.org/difusion/

Aguirre, M. 2012, Ocupaciones gravetienses de Antoliñako koba: aproximación preliminar a su estratigrafía, cronología e industrias. In: Pensando el Gravetiense: Nuevos datos para la región cantábrica en su contexto peninsular y pirenáico (De las Heras, C., Lasheras, J.A., Arrizabalaga, A. \& de la Rasilla, M., Eds.) Monografías del Museo Nacional y Centro de Investigación de Altamira Vol. 23, Ministerio de Educación y Cultura., Madrid: p. 216-228. (in Spanish) ("Gravettian occupations of Antoliñako koba: preliminary approach to the stratigraphy, chronology and industries")

Alonso, J., Pulgar, J. \& Pedreira, D. 2007, El relieve de la Cordillera Cantábrica. Enseñanza de las Ciencias de la Tierra, 15(2): 151-163. (in Spanish) ("The relief of the Cantabrian Mountains") URL: https://raco.cat/index.php/ECT/article/view/120966/167881

Álvarez-Alonso, D. \& De Andrés, M. 2012, La transición Solutrense-Magdaleniense en la Cueva de El Cierro (Ribadesella, Asturias, España). Espacio, Tiempo y Forma, Serie I, nueva época Prehistoria y Arqueología, 5: 399-411. (in Spanish) ("The SolutreanMagdalenian transition in El Cierro Cave (Ribadesella, Asturias, Spain)") doi:10.5944/etfi.5.2012.5360

Álvarez-Alonso, D., Yravedra, J., Álvarez-Fernández, E., Calvo, A., Carral, P., Iriarte, M., Jordá, F., Sesé, C., Uzquiano, P. \& Arrizabalaga, A. 2017, Subsistencia, movilidad y adaptación al medio de los cazadores-recolectores gravetienses en el sector occidental de la región cantábrica: la cueva de Coímbre (Asturias). Trabajos de Prehistoria, 74(enero-junio): 47-67. (in Spanish) ("Subsistence, mobility and environmental adaptation of the Gravettian hunter-gatherers in the western part of Cantabria: Coímbre cave (Asturias)") doi:10.3989/tp.2017.12183 
Álvaro, M., Apalategui, O., Baena, J., Balcells, R., Barnolas, A., Barrera, J.L., Bellido, F., Cueto, L.A., Díaz de Neira, A., Elízaga, E., Fernández-Gianotti, J.R., Ferreiro, E., Gabaldón, V., García-Sansegundo, J., Gómez, J.A., Heredia, N., Hernández-Urroz, J., Hernández-Samaniego, A., Lendínez, A., Leyva, F., López-Olmedo, F.L., Lorenzo, S., Martín, L., Martín, D., Martín Serrano, A., Matas, J., Monteserrín, V., Nozal, F., Olive, A., Ortega, E., Piles, E., Ramírez, J.I., Robador, A., Roldán, F., Rodríguez, L.R., Ruiz, P., Ruiz, M.T., Sánchez-Carretero, R. \& Teixell, A. 1994, Mapa geológico de la Península Ibérica, Baleares y Canarias: escala 1.1000.000. IGME, Madrid. (in Spanish) ("Geological map of the Iberian Peninsula, Balearic, and Canary islands: 1: 1.000.000")

Andrefsky, W. 1994, Raw-material availability and the organization of technology. American Antiquity, 59(1): 21-34. doi:10.2307/3085499

Arbizu, M., Arsuaga, J.L. \& Adán, G. 2005, La cueva del Forno/Conde (Tuñón, Asturias): un yacimiento del tránsito del Paleolítico medio y superior en la Cornisa Cantábrica. In: Actas de la reunión científica: Neandertales cantábricos, estado de la cuestión. Celebrada en el Museo de Altamira los días 20-22 de octubre de 2004 (Montes, R. \& Lasheras, J.A., Eds.) Monografías del Museo Nacional y Centro de Investigación de Altamira Vol. 20, Ministerio de Educación y Cultura, Madrid: p. 425-441. (in Spanish) ("The cave of el Forno/Conde (Tuñón, Asturias): a Middle-to-Upper Palaeolithic transition site in the Cantabrian Region")

Arrizabalaga, A. 1998, El aprovisionamiento en materias primas líticas durante la génesis del Leptolítico en el Cantábrico Oriental. Rubricatum: revista del Museu de Gavà, 2: 97104. (in Spanish) ("The supply of lithic raw materials during the Leptolithic in the Eastern Cantabrian Region")

Arrizabalaga, A. 2000, Los tecnocomplejos líticos del yacimiento arqueológico de Labeko Koba (Arrasate, País Vasco) Munibe, 52: 193-343.

Arrizabalaga, A. 2007, Frontières naturelles, administratives et épistémologiques: L'unité d'analyse dans l'archéologie du Paléolithique (dans le cas basque). In: Frontières naturelles et frontières culturelles dans les Pyrénées préhistoriques (Cazals, N., González, J. \& Terradas, X., Eds.), PubliCan-Ediciones de la Universidad de Cantabria, Santander: p. 27-37. (in French) ("Natural, administrative and epistemological boundaries: The unit of analysis in Palaeolithic archeology (in the Basque case)")

Arrizabalaga, A., Calvo, A., Elorrieta, I., Tapia, J. \& Tarriño, A. 2014a, Where to and what for? Mobility patterns and the management of lithic resources by Gravettian huntergatherers in the Western Pyrenees. Journal of Anthropological Research 70: 233-261. doi:10.3998/jar.0521004.0070.204

Arrizabalaga, A., Rios-Garaizar, J., Maíllo-Fernández, J.M. \& Iriarte-Chiapusso, M.J. 2014b, Identifying the signs: The Middle to Upper Palaeolithic transition in northern Iberia from the perspective of the lithic record, Journal of Lithic Studies 1(2): 155-166. doi:10.2218/jls.vli2.1064

Arrizabalaga, A., Prieto, A., García-Ibaibarriaga, N., Calvo, A., Domínguez-Ballesteros, E., Ochoa, B., Ordoño, J., Romero, A., Villaluenga, A., Tapia, J., Ayerdi, M., Echazarreta, A., Hernández-Beloqui, B., Medina, M.A., Bradmöller, M., Suarez, A., Sarasketa, I. \& Iriarte-Chiapusso, M.J. 2016, En la ruta occidental del poblamiento de la Península Ibérica. Munibe, 67: 227-234. (in Spanish) ("In the Western route for the population of Iberian Peninsula") doi:10.21630/maa.2016.67.mis03 
Arrizabalaga, A. \& Tarriño, A. 2010, Caracterización de los recursos líticos utilizados en el yacimiento paleolítico de Irikaitz (Zestoa, Gipuzkoa). Un nuevo recurso mineral: La vulcanita. In: Minerales y rocas en las sociedades prehistóricas (Domínguez-Bella, S., Ramos, J., Gutiérrez, J.M. \& Pérez, M., Eds.): p. 91-97. (in Spanish) ("Lithic raw material characterisation of the Palaeolithic site of Irikaitz (Zestoa, Gipuzkoa). A new mineral resource: The vulcanite")

Baena Preysler, J., Carrión Santafé, E., Ruiz, B., Ellwood, B., Sesé, C., Yravedra, J., Jordá, J., Uzquiano, P., Manzano, I., Sánchez-Marco, A. \& Hernández, F. 2005, Paleoecología y comportamiento humano durante el Pleistoceno Superior en la comarca de Liébana: La secuencia de la Cueva de El Esquilleu (Occidente de Cantabria, España). In: Actas de la reunión científica: Neandertales cantábricos, estado de la cuestión. Celebrada en el Museo de Altamira los días 20-22 de Octubre de 2004 (Montes, R. \& Lasheras, J.A., Eds.) Monografías del Museo Nacional y Centro de Investigación de Altamira Vol. 20, Ministerio de Cultura, Madrid: p. 461-487. (in Spanish) ("Palaeoecology and human behaviour during the Upper Pleistocene in the region of La Liébana: The archaeological sequence of la Cueva del Esquilleu (West of Cantabria, Spain)")

Baena Preysler, J., Carrión Santafé, E., Torres Navas, C. \& Vaquero Rodríguez, M. 2019, Mousterian inside the Upper Paleolithic? The last interval of El Esquilleu (Cantabria, Spain) sequence. Quaternary International, 508: 153-163. doi:10.1016/j.quaint.2018.11.015

Baldeón, A. 1990, Las industrias de los niveles paleolíticos. In: La cueva de Amalda (Zestoa, País Vasco): Ocupaciones paleolíticas y postpaleolíticas Vol. 4 (Altuna, J., Baldeón, A. \& Mariezkurrena, K., Eds.), Eusko Ikaskuntza - Sociedad de Estudios Vascos, Donostia: p. 63-115.

Baldeón, A. 1993, El yacimiento de Lezetxiki (Gipuzkoa, País Vasco). Los niveles musterienses. Munibe, 45: 3-97. (in Spanish) ("The Lezetxiki site (Gipuzkoa, Basque Country). The Mousterian levels") URL: https://www.aranzadi.eus/fileadmin/docs/Munibe/1993003097AA.pdf

Bamforth, D.B. 2006, The Windy Ridge quartzite quarry: hunter-gatherer mining and huntergatherer land use on the North American Continental Divide. World Archaeology, 38(3): 511-527. doi:10.1080/00438240600813871

Bastida, F. 1982, La esquistosidad primaria y las microestructuras de las cuarcitas en la zona Asturoccidental-leonesa. Trabajos de Geología, 12: 159-185. (in Spanish) ("Primary schistosity and microstructures on quartzites in the West Asturian Leonese Zone (NW of Spain)") URL: https://reunido.uniovi.es/index.php/TDG/article/view/2758/2623

Bastida, F. 2004, Zona Cantábrica. In: Geología de España (Vera, J.A., Ed.), SGE-IGME, Madrid: p. 25-49.

Barnolas, A. \& Pujalte, V. 2004, La cordillera pirenaica: Definición, límites y división. In: Geología de España (Vera, J.A., Ed.), SGE-IGME, Madrid: p. 233-241. (in Spanish) ("The Pyrenean mountain range: definition, limits and division")

Bernaldo de Quirós, F. \& Cabrera, V. 1996, Raw material in the Palaeolithic of cueva del Castillo and in the Cantabrian region. In: Non-flint Stone Tools and the Palaeolithic Occupation of the Iberian Peninsula Vol. 649 (Moloney, N., Raposo, L. \& Santonja, M., Eds.), British Archaeological Reports International Series, Oxford: p. 21-32. 
Binford, L.R. 1979, Organization and formation processes: Looking at curated technologies. Journal of Anthropological Research, 35(3): 255-273. doi:10.1086/jar.35.3.3629902

Binford, L.R. 1982, The archaeology of place. Journal of Anthropological Archaeology, 1(1): 5-31. doi:10.1016/0278-4165(82)90006-X

Binford, L.R. 1983, Long-term land use patterns: some implications for archaeology. In: Working at Archaeology (Binford, L.R., Ed.), Academic, New York: p. 379-386.

Binns, R.A. \& McBryde, I. 1969, Preliminary report on a petrological study of ground-edge artefacts from north-eastern New South Wales, Australia. Proceedings of the Prehistoric Society, 35(10): 229-235. doi:10.1017/S0079497X00013475

Boëda, E. 1994, Le Concept Levallois: variabilité des méthodes. CNRS editions, Paris, 283. (in French) ("The Levallois concept: variability of methods")

Brantingham, P. 2003, A neutral model of stone raw material procurement. American Antiquity, 68(3): 487-509. doi:10.2307/3557105

Cabrera, V. 1984, El yacimiento de la Cueva de"El Castillo" (Puente Viesgo, Santander). Bibliotheca Praehistorica Hispana Vol. 22. Consejo Superior de Investigaciones Científicas, Madrid, 488 p. (in Spanish) ("The archaeological site of La Cueva de El Castillo (Puente Viesgo, Santander)")

Cabrera, V., Bernaldo de Quirós, F., Maillo, J.M., Pike-Tay, A. \& Garralda, M.D. 2005, Excavaciones en El Castillo: Veinte años de reflexiones. In: Actas de la reunión científica: Neandertales cantábricos, estado de la cuestión. Celebrada en el Museo de Altamira los días 20-22 de Octubre de 2004 (Montes, R. \& Lasheras, J.A., Eds.) Monografías del Museo Nacional y Centro de Investigación de Altamira Vol. 20, Ministerio de Educación y Cultura, Madrid: p. 503-526. (in Spanish) ("Archaeological excavation at El Castillo: Twenty years of reflecions")

Calvo, A. 2019, El Gravetiense en el Pirineo occidental: dinámicas de aprovisionamiento y gestión tecnológica de las materias primas líticas. Doctoral thesis at the Departamento de Geografía, Prehistoria y Arqueología, Universidad del País Vasco (UPV/EHU), Vitoria-Gasteiz, 682 p. (in Spanish) ("The Gravettian in the Western Pyrenees: Dynamics of procurement and technological management of lithic raw materials")

Calvo, A. \& Arrizabalaga, A. 2020, Piecing together a new mosaic: Gravettian lithic resources and economic territories in the Western Pyrenees. Archaeological and Anthropological Sciences, 12(12): 282. doi:10.1007/s12520-020-01231-X

Calvo, A., Tapia, J., Arrizabalaga, A. \& Iriarte-Chiapusso, M.J. 2013, El yacimiento de Ametzagaina (Donostia, País Vasco). Un campamento gravetiense al aire libre en el Cantábrico. In: Pensando el Gravetiense: Nuevos datos para la región cantábrica en su contexto peninsular y pirenáico (De las Heras, C., Lasheras, J.A., Arrizabalaga, A. \& de la Rasilla, M., Eds.) Monografías del Museo Nacional y Centro de Investigación de Altamira Vol. 23, Ministerio de Educación y Cultura, Madrid: p. 229-241. (in Spanish) ("The archaeological site of Ametzagaina (Donostia, Basque Country). A Gravettian open air campsite in the Cantabrian region")

Cann, J.R. \& Renfrew, C. 1964, The characterization of obsidian and its application to the Mediterranean region. Proceedings of the Prehistoric Society, 30: 111-133. doi:10.1017/S0079497X00015097 
Carrión, E. \& Baena, J. 2005, El Habario: una ocupación musteriense al aire libre en los Picos de Europa. In: Actas de la reunión científica: Neandertales cantábricos, estado de la cuestión. Celebrada en el Museo de Altamira los días 20-22 de Octubre de 2004 (Montes, R. \& Lasheras, J.A., Eds.) Monografías del Museo Nacional y Centro de Investigación de Altamira Vol. 20, Ministerio de Educación y Cultura, Madrid: p. 446460. (in Spanish) ("El Habario: a Mousterian open-air occupation at Picos de Europa")

Castanedo, I. 2001, Adquisición y aprovechamiento de los recursos líticos en la Cueva de la Flecha. Munibe, 53: 3-18. (in Spanish) ("Procurement and use of lithic resources in La Flecha Cave (Cantabria)")

Clark, G. 1965, Traffic in stone axe and adze blades. The Economic History Review, 18(1): 128. doi:10.2307/2591871

Corchón, M.S. 1981, Cueva de las Caldas: San Juan de Priorio (Oviedo). Excavaciones arqueológicas en España Vol. 115. Ministerio de Cultura de España, Madrid, 482 p. (in Spanish) ("Las Caldas cave: San Juan de Priorio (Oviedo)")

Corchón, M.S., Martínez, J. \& Tarriño, A. 2009, Mobilité, territoires et relations culturelles au début du Magdalénien moyen cantabrique: nouvelles perspectives. In: Le concept de territoires dans le Paléolithique supérieur européen. Actes du XVe Congrès mondial UISPP (Lisbonne, 4-9 septembre 2006) Vol. 1983 (Djindjian, F., Kozlowski, J. \& Bicho, N., Eds.), BAR International Series, Oxford: p. 217-230. (in French) ("Mobility, territoriality and cultural relations at the beginning of the Cantabrian middle Magdalenian: New perspectives")

Cronk, L. 1991, Human behavioural ecology. Annual Review of Anthropology, 20: 25-53.

Daffara, S., Berruti, G.L.F., Berruto, G., Eftekhari, N., Vaccaro, C. \& Arzarello, M. 2019, Raw materials procurement strategies at the Ciota Ciara cave: New insight on land mobility in north-western Italy during Middle Palaeolithic. Journal of Archaeological Science: Reports, 26: 101882. doi:10.1016/j.jasrep.2019.101882

Demars, P.Y. 1980, Les matières premières utilisées au Paléolithique supérieur dans le Bassin de Brive. Doctoral thesis at Université de Bordeaux, Bordeaux, 173 p. (in French) ("Raw materials used during the Upper Palaeolithic in the Brive Basin")

Dixon, J.E., Cann, J.R. \& Renfrew, C. 1968, Obsidian and the origins of trade. Scientific American, 218: 38-46.

Duarte, E., Santamaría, D., Forcelledo, E., Tarriño, A. \& de la Rasilla, M. 2016, El sílex como recurso mineral en la Prehistoria de Asturias. Cuadernos de Prehistoria de la Universidad de Granada, 26: 157-190. (in Spanish) ("Flint as mineral source in the prehistory of Asturias")

Durrani, S.A., Khan, H.A. \& Renfrew, C. 1970, Obsidian source identification by fission track analysis. Nature, 233(5317): 242-245. doi:10.1038/233242a0

Elorrieta, I. 2016, Aprovisionamiento y disponibilidad de las materias primas silíceas en el Pirineo Occidental durante el Paleolítico Superior. Doctoral thesis at the Departamento de Geografía, Prehistoria y Arqueología, Universidad del País Vasco/Euskal Herriko Unibertsitatea, Vitoria-Gasteiz, 451 p. (in Spanish) ("Supply and availability of siliceous raw materials in the Western Pyrenees during the Upper Palaeolithic”)

Elorza, M. \& Bustillo, M.A. 1989, Early and late diagenetic chert in carbonate turbidites of the Senonian Flysch, Northeast Bilbao. In: Siliceous deposits of the Tethys and Pacific Regions (Hein, J.R. \& Obradovic, J., Eds.), Springer-Verlag, New York: p. 93-106. 
Fernández, L.P., Bahamonde, J.R., Barba, P., Colmenero, J.R., Heredia, N., RodríguezFernándezL.R., Salvador, C., Sánchez de Posada, L.C., Villa, E., Merino-Tomé, O. \& Motis, K. 2004, Secuencia sinorogénica. In: Geología de España (Vera, J.A., Ed.), SGE-IGME, Madrid: p. 34-42. (in Spanish) ("Sinogenic sequence”)

Fernández-Eraso, J., García-Rojas, M., Sánchez, A., Prieto, A., Calvo, A., DomínguezBallesteros, E., Tarriño, A., López-de-Ocáriz, J., Bradtmöller, M. \& Urigoitia, T. 2017, El tecno-complejo del Embalse de Urrúnaga (Álava). Nuevas aportaciones al conocimiento de las sociedades del Paleolítico inferior en el norte de la Península Ibérica. Munibe, 68: 5-31. (in Spanish) ("The techno-complex of the Urrúnaga Reservoir (Álava). New contributions to the knowledge of the Lower Paleolithic societies in the north of the Iberian Peninsula”) doi:10.21630/maa.2017.68.04

Floss, H. 1990, Rohmaterialversorgung im Paläolithikum des Mittelrheingebietes. Dissertation Universität zu Köln. Monographien. Habelt, Bonn, 407 p. (in German) ("Raw material procurement during the Palaolithic in the Middle Rhine Valley")

Fontes, L.M. 2016, The Initial Magdalenian mosaic: New evidence from Urtiaga cave, Guipúzcoa, Spain. Journal of Anthropological Archaeology, 41: 109-131. doi:10.1016/j.jaa.2015.11.006

Fontes, L.M., Straus, L.G. \& González Morales, M.R. 2018, Lower Magdalenian lithic raw material provisioning: A diachronic view from El Mirón cave (Ramales de la Victoria, Cantabria, Spain). Journal of Archaeological Science: Reports, 19: 794-803. doi:10.1016/j.jasrep.2017.03.015

Freeman, L.G. 1980, Ocupaciones musterienses. In: El yacimiento de la cueva de "El Pendo" (excavaciones 1953-57) (González Echegaray, J., Ed.) Bibliotheca Praehistorica Hispana Vol. 27, Consejo Superior de Investigaciones Científicas, Madrid: p. 29-74. (in Spanish) ("Mousterian ocupations")

Fuertes-Prieto, N., Fernández-Martínez, E., Gómez-Fernández, F., Alonso-Herrero, E., Herrero-Alonso, D. \& Neira-Campos, A. 2016, The Escalada Formation: Characterization of a potential chert supply source in the Cantabrian Mountains (NW Spain) during prehistory. Journal of Lithic Studies, 3(2): 309-326. doi:10.2218/jls.v3i2.1421

García-Rojas, M. 2014, Dinámicas de talla y gestión de las materias primas silíceas a finales del Pleistoceno en el País Vasco. Doctoral thesis at the Departamento de Geografía, Prehistoria y Arqueología, Universidad del País Vasco/Euskal Herriko Unibertsitatea, Vitoria-Gasteiz, 558 p. (in Spanish) ("Knapping processes and management of siliceous raw material at the end of the Pleistocene in the Basque Country")

García-Rojas, M., Prieto, A., Sánchez, A., Camarero, C. \& Zapata, L. 2017, The application of GIS to flint management studies during the Pleistocene to Holocene transition: the case of Baltzola (Dima, Bizkaia, Spain). In: Archaeology and Geomatics. Harvesting the benefits of 10 years of training in the Iberian Peninsula (2006-2015) (Mayoral Herrera, V., Parcero-Oubiña, C. \& Fábrega-Álvarez, P., Eds.), Sidestone Press, Leiden: p. $133-148$.

Geneste, J.M. 1985, Analyse lithique d'industries moustériennes du Périgord: une approche du comportement des groupes humains au paléolithique moyen. Doctoral thesis at Université de Bordeaux, Bordeaux, 572 p. (in French) ("Lithic analysis on the Mousterian Perigord: an approach to the behaviours of human group during in the Middle Palaeolithic") 
González Echegaray, J. 1980, El Paleolítico superior. Industria lítica. In: El yacimiento de la cueva de "El Pendo" (excavaciones 1953-57) (González Echegaray, J., Ed.) Bibliotheca Praehistorica Hispana Vol. XVII, Consejo Superior de Investigaciones Científicas, Madrid: p. 75-145. (in Spanish) ("The Upper Palaeolithic. Lithic industries")

González Echegaray, J. 1981, Industria lítica. In: El Paleolítico superior de la cueva del Rascaño (Santander) (González Echegaray, J. \& Barandiarán, I., Eds.) Monografías del Centro de Investigación y Museo de Altamira Vol. 3, Ministerio de Cultura de España, Santander: p. 57-94. (in Spanish) ("Lithic industry")

González Echegaray, J. 1987, La industria lítica. In: Excavaciones en la Cueva del Juyo (Barandiarán, I., Freeman, J., González Echegaray, J. \& Klein, R.G., Eds.) Monografías del Museo Nacional y Centro de Investigación de Altamira Vol. 14, Minsterio de Cultura, Madrid: p. 121-153. (in Spanish) ("Lithic industry")

González Echegaray, J. \& Freeman, L., (Eds.) 1978, Vida y muerte en Cueva Morín. Institución cultural de Cantabria. Diputación Provincial, Santander, 357 p. (in Spanish) ("Life and death at Cueva Morín")

González Morales, M.R. \& Straus, L. 2012, La ocupación gravetiense de la cueva de El Mirón (Ramales de la Victoria, Cantabria) y el contexto del arte paleolítico temprano de la cuenca del Asón. In: Pensando el Gravetiense: Nuevos datos para la región cantábrica en su contexto peninsular y pirenáico (De las Heras, C., Lasheras, J.A., Arrizabalaga, A. \& de la Rasilla, M., Eds.) Monografías del Museo Nacional y Centro de Investigación de Altamira Vol. 23, Ministerio de Educación y Cultura., Madrid: p. 289-300. (in Spanish) ("The Gravettian occupation of the El Mirón cave (Ramales de la Victoria, Cantabria) and the context of early Palaeolithic art in the Asón basin ")

González Sainz, C. 1991, Algunas reflexiones sobre las materias primas líticas y la variabilidad técnica y tipológica, al término del Paleolítico superior de la Región Cantábrica. Treballs d'arqueologia, 1: 57-72. (in Spanish) ("Some reflections on lithic raw materials and technical and typological variability, at the end of the Upper Palaeolithic of the Cantabrian Region”)

Gould, R. 1978, The anthropology of human residues. American Anthropologist: 215-235. doi:10.1525/aa.1978.80.4.02a00030

Groucutt, H.S., Scerri, E.M.L., Amor, K., Shipton, C., Jennings, R.P., Parton, A., ClarkBalzan, L., Alsharekh, A. \& Petraglia, M.D. 2017, Middle Palaeolithic raw material procurement and early stage reduction at Jubbah, Saudi Arabia. Archaeological Research in Asia, 9: 44-62. doi:10.1016/j.ara.2017.01.003

Herrero-Alonso, D. 2018, La gestión de las materias primas y cadenas operativas líticas en el Mesolítico de la vertiente sur de los Picos de Europa: la cueva de La Uña (León). Doctoral thesis at the Departamento de Prehistoria, Historia Antigua y Arqueología, Universidad de Salamanca, Salamanca, 1098 p. (in Spanish) ("Management of raw material and reduction sequences in the Mesolithic of the southern watershed of Picos de Europa: La Cueva de la Uña (León)")

Herrero-Alonso, D., Fuertes-Prieto, N. \& Neira-Campos, A. 2020, Management of lithic raw materials in the "Mesolithic with geometrics" (Northern of Iberian Peninsula): chaînes opératoires and territory. Journal of Archaeological Science: Reports, 29: 1-13. doi:10.1016/j.jasrep.2019.102093 
Herrero-Alonso, D., Tarriño, A., Neira-Campos, A. \& Fuertes-Prieto, N. 2016, Chert from the Vegamián Formation: A new raw-material supply source in the Cantabrian Mountains (NW Spain) during prehistory. Journal of Lithic Studies, 3(2): 389-410. doi:10.2218/jls.v3i2.1449

Herrero-Alonso, D., Fuertes-Prieto, N., Fernández-Martínez, E., Gómez-Fernández, F., Alonso-Herrero, E. \& Matero-Pellitero, A.M. 2018, LegioLit: Knappable material lithotheque in the Prehistory Laboratory at the University of León, Spain. Journal of Lithic Studies, 5(2): 1-16. doi:10.2218/jls.2926

Howard, J.L. 2005, The quartzite problem revisited. The Journal of Geology, 113(6): 707713. doi:10.1086/449328

Hoyos, M., Martínez, M.I., Chapa, T., Castaños, P. \& Sanchiz, F.B. 1980, La cueva de la Paloma. Excavaciones arqueológicas en España. Dirección General de Bellas Artes, Archivos y Bibliotecas, Ministerio de Cultura, Madrid, 227 p. (in Spanish) ("La Paloma Cave")

IGN 2020, Centro de descargas. Retrieved 2/01/2020 2020.

URL: http://centrodedescargas.cnig.es/CentroDescargas/catalogo.do?Serie=RTANE

Iriarte-Chiapusso, M.J., Álvarez-Fernández, E., Aramburu, A., Areitio, I., Ayerdi, M., Barandiarán, I., Bilbao, P., Castaños, P., Castaños, J., García-Díez, M., GarcíaIbaibarriaga, N., Murelaga, X., Ordiales, A., Prieto, A., Suárez-Bilbao, A., Yusta, I. \& Arrizabalaga, A. 2015, La Cueva de Bolinkoba (Abadiño) y su yacimiento arqueológico. Secuencia geoarqueológica e intento de síntesis del proceso de excavación y de la serie arqueológica recuperada en las sucesivas investigaciones. Kobie, BAI 6: 173-182. (in Spanish) ("The archaeological site of Bolinkoba (Abadiño, Bizkaia). Geoarchaeological sequence and attempts to synthesize the excavation process and the archaeological series recovered in successive investigations")

Jeske, R. 1989, Economies in raw material use by prehistoric hunter-gatherers. In: Time, Energy and Stone Tools (Torrence, R., Ed.), Cambridge University, Cambridge: p. 3445.

Kelly, R.L. 1995, The Foraging Spectrum. Diversity in Hunter-Gatherer Lifeways. Percheron Press, New York, 446 p.

Knutsson, K. 2014, 'Simple’ need not mean ‘archaic'. Antiquity, 88(341): 950-953. doi:10.1017/S0003598X00050894

Kowalski, B.R., Schatzki, T.F. \& Stross, F.H. 1972, Classification of archaeological artifacts by applying pattern recognition to trace element data. Analytical Chemistry, 44: 21762180. doi:10.1021/ac60321a002

Laplace, G. 1972, La typologie analytique et structurale: Base rationelle d'études des industries lithiques et osseuses. Banques de Données Archéologiques, 932: 91-143. (in French) ("Analytical and structural typology: Rational basis for studies of lithic and bone industries")

Laplace, G. 1987, Un exemple de nouvelle écriture de la grille typologique. Dialktikê. Cahiers de Typologie Analytique, 1985-1987: 16-21. (in French) ("An example of a new writing of the typological grid")

Leroi-Gourhan, A. 1964, Le geste et la parole. Michel Albin, París, 326 p. (in French) ("Gesture and Speech") 
de Lombera-Hermida, A. 2008, Quartz morphostructural groups and their mechanical implications. Annali dell’Università degli Studi di Ferrara: 5: 101-104.

de Lombera-Hermida, A. \& Rodríguez-Rellán, C. 2016, Quartzes matter. Understanding the technological and behavioural complexity in quartz lithic assemblages. Quaternary International, 424: 2-11. doi: 10.1016/j.quaint.2016.11.039

Luedtke, B. 1979, The indentification of sources of chert artifacts. American Antiquity, 44(4): 744-757. doi:10.2307/279116

Mangado, J. 1998, La arqueopetrología del sílex. Estudio de caracterización de materiales silíceos. Un caso práctico, el nivel II de la Cova del Parco (Alòs de Balaguer, La Noguera). Pyrenae, 29: 47-68. (in Spanish) ("Flint archaeopetrology. Characterisation of siliceous material. A practical example, the level II from Cova del Parco (Alòs de Balaguer, La Noguera)")

Manzano, I., Baena, J., Lázaro, A., Martín, D., Dapena, L., Roca, M. \& Moreno, E. 2005, Análisis de los recursos líticos en la Cueva del Esquilleu: gestión y comportamiento durante el Musteriense (Comarca de la Liébana, Occidente de Cantabria). In: Actas de la reunión científica: Neandertales cantábricos, estado de la cuestión. Celebrada en el Museo de Altamira los días 20-22 de Octubre de 2004 (Montes, R. \& Lasheras, J.A., Eds.) Monografías del Museo Nacional y Centro de Investigación de Altamira Vol. 20, Ministerio de Educación y Cultura, Madrid: p. 285-300.

Martínez, L. \& de la Rasilla, M. 2012, El Gravetiense en Asturias: revisión y novedades. In: Pensando el Gravetiense: Nuevos datos para la región cantábrica en su contexto peninsular y pirenáico (De las Heras, C., Lasheras, J.A., Arrizabalaga, A. \& de la Rasilla, M., Eds.) Monografías del Museo Nacional y Centro de Investigación de Altamira Vol. 23, Ministerio de Educación y Cultura., Madrid: p. 276-288. (in Spanish) ("The Gravettian in Asturias: review and news")

Masson, A. 1981, Pétroarchéologie des roches siliceuses. Intérêt en Prehistoire. Doctoral thesis at Université Claude Bernard-Lyon I, Lyon, 82 p. (in French) ("Petroarchaeology of siliceous rocks. Its interest on the Prehistory")

Mathias, C., Bourguignon, L., Brenet, M., Grégoire, S. \& Moncel, M.-H. 2020, Between new and inherited technical behaviours: a case study from the Early Middle Palaeolithic of Southern France. Archaeological and Anthropological Sciences, 12(7): 146. doi:10.1007/s12520-020-01114-1

McHenry, L.J. \& de la Torre, I. 2018, Hominin raw material procurement in the OldowanAcheulean transition at Olduvai Gorge. Journal of Human Evolution, 120: 378-401. doi:10.1016/j.jhevol.2017.11.010

Montes, R. \& Muñoz, E. 1992, Un nuevo yacimiento Paleolítico de superficie en Asturias: Panes II (Peñamellera Baja). Boletín de Ciencias Naturales, 42: 183-197. (in Spanish) ("A new open-air palaeolithic site in Asturias: Panes II (Peñamellera Baja)")

Morala, A. 1979, Étude préliminaire de la station aurignacienne des Ardailloux, commune de Soturac (Lot). Bulletin de la Société des Études du Lot, 3(juillet-septembre): 195-201. (in French) ("Preliminary research at the Aurignacian site of Ardaillous, commune of Soturac (Lot)") 
Morala, A. 1980, Observations sur le Périgordien et l'Aurignacien et leurs matières premiéres lithiques en Haute-Agenais. Doctoral thesis at Université de Toulouse, 190 p. (in French) ("Observations on the Perigodian and the Aurignacian and their lithic raw materials in Haute-Agenais ")

Morala, A. 1983, À propos des matières premières lithiques en Haut-Agenais. Bulletin de la Société Préhistorique Française, 80(6): 169. (in French) ("About lithic raw material in Haut-Agenais")

Muñoz, E. \& Serna, A. 1999, Los niveles solutrenses de la Cueva del Ruso I. Sautuola: Revista del Instituto de Prehistoria y Arqueología, 6: 161-176. (in Spanish) ("The Solutrean levels from Cueva del Ruso I (Igollo de Camargo, Cantabria)")

Normand, C. 1986, Inventaire des gîtes de matières premières de la Chalosse. In: Recherches de Préhistoire dans les Landes (Arambourou, R.L., Straus, L. \& Normand, C., Eds.) Bulletin de la Société de Borda: p. 121-140. (in French) ("Inventory of deposits of raw material in Chalosse")

Pelayo López, F. \& Gonzalo Gutiérrez, R. 2012, Juan Vilanova y Piera (1821-1893), la obra de un naturalista y prehistoriador valenciano. Serie de Trabajos Varios Vol. 114. Diputación de Valencia, Valencia, 337 p. (in Spanish) ("Juan Vilanova y Piera (18211893), the work of a Valencian naturalist and prehistorian ")

Perales, U. 2015, Traceología de la industria lítica de Atxoste (Álava): Aproximación a la gestión económico-social del asentamiento en el final del mesolítico e inicios del neolítico. Doctoral thesis at the Departamento de Geografía, Prehistoria y Arqueología, Universidad del País Vasco, 581 p. (in Spanish) ("The use wear traces from the lithic assemblage of Atxoste (Alava): An approach towards the socio-economic management of the site at the final Mesolithic and the initial Neolithic ")

URL: http://hdl.handle.net/10810/16031

Pérez-Estaún, A., Bea, F., Bastida, F., Marcos, A., Martínez Catalán, J.R., Martínez Poyatos, D., Arenas, R., Díaz García, F., Azor, A., Simancas, J.F. \& González Lodeiro, F. 2004, La Cordillera Varisca Europea: El Macizo Ibérico. In: Geología de España (Vera, J.A., Ed.), SGE-IGME, Madrid: p. 21-25.

Pinto-Llona, A.C., Clark, G., Karkanas, P., Blackwell, B., Skinner, A., Andrews, P., Reed, K., Miller, A., Macías-Rosado, R. \& Vakiparta, J. 2012, The Sopeña rockshelter, a new site in Asturias. Munibe, 63: 45-79.

Pinto-Llona, A.C., Clark, G., Miller, A. \& Reed, K. 2009, Neanderthals and Cro-Magnons in northern Spain: Ongoing work at the Sopeña rock-shelter (Asturias, Spain). In: The Mediterranean from 50000 to 25000. Turning points and new directions (Camps, M. \& Szmidt, C., Eds.), Oxbow Books, Oxford: p. 313-322.

Polanyi, K. 1957, The economy as instituted process. In: Trade and market in the early empires (Polanyi, K., Arensberd, C. \& Pearson, H., Eds.), Free Press, New York: p. 243-270.

Prieto, A. 2018, Procurement and management of quartzite in the Cantabrian Region: The Middle and Upper Palaeolithic in the Deva, Cares and Güeña Valleys. Doctoral thesis at the Departamento de Geografía, Prehistoria y Arqueología, Universidad del País Vasco, 589 p. 
Prieto, A., García-Rojas, M., Sánchez, A., Calvo, A., Domínguez-Ballesteros, E., Ordoño, J. \& García Collado, M.I. 2016, Stones in Motion: Cost units to understand flint procurement strategies during the Upper Palaeolithic in the south-western Pyrenees using GIS. Journal of Lithic Studies, 3(1): 133-160. doi:10.2218/jls.v3i1.1310

Prieto, A., Yusta, I. \& Arrizabalaga, A. 2019a, Defining and Characterizing Archaeological Quartzite: Sedimentary and Metamorphic Processes in the Lithic Assemblages of El Habario and El Arteu (Cantabrian Mountains, Northern Spain). Archaeometry, 61(1): 14-30. doi:10.1111/arcm.12397

Prieto, A., Yusta, I., Pastoors, A. \& Claßen, E. 2019b, Petrological characterisation of the "Tertiary quartzites" from the site of Troisdorf-Ravensberg (North Rhine-Westphalia, Germany): first insights in Middle Palaeolithic outcrop exploitation. Quartär, 66: 33-50. doi:10.7485/QU66_2

Prieto, A., Yusta, I. \& Arrizabalaga, A. 2020, From petrographic analysis to stereomicroscopic characterisation: a geoarchaeological approach to identify quartzite artefacts in the Cantabrian Region. Archaeological and Anthropological Sciences, 12(1): 32. doi:10.1007/s12520-019-00981-7

Prieto, A., Yusta, I., García-Rojas, M., Arrizabalaga, A. \& Baena Preysler, J. 2021, Quartzite procurement in conglomerates and deposits: Geoarchaeological characterization of potential catchment areas in the central part of the Cantabrian Region, Spain. Geoarchaeology, 36(3): 490-510. doi:10.1002/gea.21838

Renfrew, C. 1973, Before Civilization. Pimlico, London, 292 p.

Pujalte, V., Robles, S., García-Ramos, J.C. \& Hernández, J.M. 2004, El Malm-Barremiense no marinos de la Cordillera Cantábrica. In: Geología de España (Vera, J.A., Ed.), SGEIGME, Madrid: p. 288-291. (in Spanish) ("The Malm-Barremian non-marine of the Cantabrian Mountains”)

de la Rasilla, M. \& Fernández de la Vega, J. 2014, El Solutrense en Asturias. Entemu, XVIII: Los grupos cazadores-recolectores paleolíticos del occidente cantábrico. Estudios en homenaje a Francisco Jordá Cerdá en el centenario de su nacimiento. 1914-2014: 157169. (in Spanish) ("Solutrean in Asturias")

Rios-Garaizar, J. 2007, Industria lítica y sociedad en la Transición del Paleolítico Medio al Superior en torno al Golfo de Bizkaia. Doctoral thesis at the Departamento de Ciencias Históricas, Universidad de Cantabria, Santander, 561 p. (in Spanish) ("Lithic industries and society in the Middle to Upper Palaeolithic Transition in the Biscay Gulf")

Rios-Garaizar, J. 2013, Industria lítica de los niveles del Paleolítico medio antiguo y Paleolítico superior de la Cueva de Arlanpe (Lemoa, Bizkaia). Kobie, BAI 3: 177-253. (in Spanish) ("Early Middle Palaeolithic and Upper Palaeolithic assemblages from Arlanpe cave (Lemoa, Biscay)")

Rios-Garaizar, J. 2020, Microlithic lithic technology of Neandertal shellfishers from El Cuco rockshelter (Cantabrian Region, northern Spain). Journal of Archaeological Science: Reports, 30: 102201. doi:10.1016/j.jasrep.2020.102201 
Rios-Garaizar, J., De la Peña, P. \& San Emeterio Gómez, A. 2011, Estudio de las industrias líticas y óseas de la cueva de Aitzbitarte III (Zona de la entrada). In: Ocupaciones humanas en Aitzbitarte III (País Vasco) 33.600-18.400 BP (Zona de entrada a la cueva) Vol. 5 (Altuna, J., Mariezkurrena, K. \& Ríos-Garaizar, J., Eds.) EKOB Vol. 5, Publicaciones Gobierno Vasco, Vitoria-Gasteiz: p. 79-351. (in Spanish) ("Analysis of the lithic and bone industry of the Aitzbitarte III Cave (Entrance to the cave)")

Rissetto, J.D. 2009, Late Pleistocene Hunter-Gatherer mobility patterns and lithic exploitation in Eastern Cantabria (Spain). Doctoral thesis at the Department of Anthropology, University of New Mexico, Albuquerque, 336 p.

Rissetto, J.D. 2012, Using least cost path analysis to reinterpret Late Upper Paleolithic huntergatherer procurement zones in Northern Spain. In: Least Cost Analysys of Social Landscapes. Archaeological Case Studies (White, D.A. \& Surface-Evans, S.L., Eds.), University of Utah Press, Salt Lake City: p. 11-31.

Rodríguez Asensio, J.A. \& Barrera Logares, J.M. 2012, Las ocupaciones solutrenses de las cuevas de la Lluera. Excavaciones Arqueológicas en Asturias 2007-2012: 87-108. (in Spanish) ("Solutrean occupancy at La Lluera cave systems")

Roebroeks, W. 1988, From find scatters to early hominid behaviour: a study of Middle Palaeolithic riverside settlements at Maastrich-Belvédere (The Neanderlands). Analecta Praehistorica Leidensia Vol. 21. Sidestone Press, Leiden, 175 p.

Sánchez, A., Domínguez-Ballesteros, E., García-Rojas, M., Prieto, A., Calvo, A. \& Ordoño, J. 2016, Patrones de aprovisionamiento de sílex de las comunidades superopaleolíticas del Pirineo occidental: el "coste” como medida de análisis a partir de los SIG. Munibe, 67: 235-252. (in Spanish) ("Flint procurement patterns of Upper Palaeolithic communities of the western Pyrenees: "cost” as a measure of analysis using GIS") doi:10.21630/maa.2016.67.mis02

Sanguino, J. \& Montes, R. 2005, Nuevos datos para el conocimiento del Paleolítico medio en el centro de la Región Cantábrica: La Cueva de Covalejos. In: Actas de la reunión científica: Neandertales cantábricos, estado de la cuestión. Celebrada en el Museo de Altamira los días 20-22 de Octubre de 2004 (Montes, R. \& Lasheras, J.A., Eds.) Monografías del Museo Nacional y Centro de Investigación de Altamira Vol. 20, Ministerio de Educación y Cultura, Madrid: p. 489-504. (in Spanish) ("New data to the knowledge of Middle Palaeolithic in the centre of the Cantabrian Region: La Cueva de Covalejos")

Santamaría, D. 2012, La transición del Paleolítico medio al superior en Asturias. El abrigo de La Viña (Oviedo, Asturias) y la cueva de El Sidrón (Borines, Piloña). Doctoral thesis at the Departamento de Historia, Universidad de Oviedo, 1518 p. (in Spanish) ("The Middle to Upper Palaeolithic transition in Asturias. The rockshelter of La Viña (Oviedo, Asturias) and the Cave of El Sidrón (Borines, Piloña)")

Santamaría, D., Fortea, J., De La Rasilla, M., Martínez, L., Martínez, E., Cañaveras, J.C., Sánchez-Moral, S., Rosas, A., Estalrrich, A., García-Tabernero, A. \& Lalueza-Fox, C. 2010, The technological and typological behaviour of a Neanderthal group from El Sidrón Cave (Asturias, Spain), 29(2): 119-148. doi:10.1111/j.1468-0092.2010.00342.x 
Santamaría, D., De la Rasilla, M., Martínez, L. \& Tarriño, A. 2011, Las Herramientas y su interpretación cultural y económica. In: La cueva de El Sidrón (Borines, Piloña, Asturias): investigación interdisciplinar de un grupo neandertal (de la Rasilla, M., Ed.), Gobierno del Principado de Asturias, Oviedo: p. 21-30. (in Spanish) ("The tools and its cultural and economic interpretation")

Sarabia, P. 1999, Notas sobre los modelos de aprovisionamiento de materias primas líticas en el Paleolítico superior de Cueva Morín. Sautuola: Revista del Instituto de Prehistoria y Arqueología, 6: 145-154. (in Spanish) ("Notes about raw material procurement in the Upper Palaeolithic at Cueva Morín")

Sarabia, P. 2000, Aprovechamiento y utilización de las materias primas líticas en los tecnocomplejos del Paleolítico en Cantabria. Doctoral thesis at the Departamento de Ciencias históricas, Universidad de Santander, Santander, 840 p. (in Spanish) ("Exploitation and use of lithic raw material in the Palaolithic techno-complexes at Cantabria")

Schmidt, I. 2013, The Solutrean Concave Based Points from northern Spain: Analysis of Production, Hafting, Maintenance and Recycling. In: Pleistocene Foragers: Their Culture and Environment. Festschrift in honour of Gerd-Christian Weniger for his sixtieth birthday (Pastoors, A. \& Auffermann, B., Eds.) Wissenschaftliche Schriften des Neanderthal Museums Vol. 6, Neanderthal Museum, Mettmann: p. 71-84.

Sieveking, G., Bush, P., Ferguson, J., Craddock, P.T., Hughes, M.J. \& Cowell, M.R. 1972, Prehistoric flint mines and their identification as sources of raw material. Archaeometry, 14(2): 151-176. doi:10.1111/j.1475-4754.1972.tb00061.x

Simonet, R. 1981, Carte des gîtes à silex des Pré-Pyrénées. In: Congrés Préhistorique de France Vol. 1, Quercy: p. 308-323. (in French) ("Flint outcrops map for the Prepyrenees")

Skolnick, H. 1965, The quartzite problem. Journal of Sedimentary Petrology, 35(1): 12-21

Soto, M., Favreau, J., Campeau, K., Carter, T., Abtosway, M., Bushozi, P.M., Clarke, S., Durkin, P.R., Hubbard, S.M., Inwood, J., Itambu, M., Koromo, S., Larter, F., Lee, P., Mwambwiga, A., Nair, R., Olesilau, L., Patalano, R., Tucker, L. \& Mercader, J. 2020, Fingerprinting of quartzitic outcrops at Oldupai Gorge, Tanzania. Journal of Archaeological Science: Reports, 29: 102010. doi:10.1016/j.jasrep.2019.102010

Straus, L. 1975, El Solutrense de las cuevas del Castillo y Hornos de la Peña (Santander) en el Museo Arqueológico Nacional de Madrid. Trabajos de Prehistoria, 32: 9-19.

Straus, L. 1983, El Solutrense vasco-cantábrico, una nueva perspectiva. Monografías del Museo Nacional y Centro de Investigación de Altamira Vol. 10. Ministerio de Educación y Cultura, Madrid, 173 p. (in Spanish) ("The Basque-Cantabrian Solutrean, a new perspective")

Straus, L. 1992, Iberia before the Iberians. The Stone Age Prehistory of Cantabrian Spain. University of New Mexico Press, Albuquerque, 336 p.

Straus, L. 1996, The use of quartzite in the Upper Palaeolithic of Catabrian Spain. In: Nonflint Stone Tools and the Palaeolithic Occupation of the Iberian Peninsula Vol. 649 (Moloney, N., Raposo, L. \& Santonja, M., Eds.), British Archaeological Reports International Series, Oxford: p. 37-41.

Straus, L. 2001, Solutrean. In: Encyclopedia of Prehistory Vol. 4 (Peregrine, P. \& Ember, M., Eds.), Kluwer Academic/Plenum, New York: p. 238-250. 
Straus, L. 2012, El Solutrense: 40 años de reflexiones por un arqueólogo norteamericano.

Espacio, Tiempo y Forma, Serie I, nueva época Prehistoria y Arqueología, 5: 27-36. (in Spanish) ("The Solutrean: 40 years of reflections by a North American archaeologist") doi:10.5944/etfi.5.4768

Straus, L., Clark, G., Ordaz, J., Suárez, L. \& Esbert, R. 1986, Patterns of lithic raw material variation at La Riera. In: La Riera Cave, Stone Age hunter-gatherer adaptations in Northern Spain Vol. 36 (Straus, L. \& Clark, G., Eds.), Arizona State University, Arizona: p. 189-208.

Tarriño, A. 1998, Rocas silíceas sedimentarias. Su composición mineralógica y terminología. KREI, 3: 143-161. (in Spanish) ("Sedimentary siliceous rocks. Mineral composition and terminology")

Tarriño, A. 2000, Estudio de la procedencia de los sílex recuperados en el yacimiento de Labeko Koba (Arrasate, País Vasco). In: Labeko Koba (País Vasco): Hienas y Humanos en los albores del Paleolítico superior Vol. 52 (Arrizabalaga, A. \& Altuna, J., Eds.), Munibe p. 345-354. (in Spanish) ("Provenience analysis of the chert from the site of Labeko Koba (Arrasate, Basque Country)")

Tarriño, A. 2001, El sílex en la Cuenca Vasco Cantábrica y Pirineo Navarro:

Caracterización y su aprovechamiento en la Prehistoria. Doctoral thesis at the Departamento de Mineralogía y Petrología, Universidad del País Vasco, Leioa, 384 p. (in Spanish) ("Flint in the Basque Cantabrian Basin and the Navarrese Pyrenees: Characterisation and Exploitation in Prehistory")

Tarriño, A. 2006, El sílex en la Cuenca Vasco-Cantábrica y Pirineo Navarro: caracterización y su aprovechamiento en la Prehistoria. Monografías del Museo Nacional y Centro de Investigación de Altamira Vol. 21. Ministerio de Educación y Cultura, Madrid. (in Spanish) ("Flint in the Basque Cantabrian Basin and the Navarrese Pyrenees: Characterisation and Exploitation in Prehistory ")

Tarriño, A. 2011a, Procedencia de los sílex de la cueva de Aitzbitarte-III (Rentería, Gipuzkoa). In: Ocupaciones humanas en Aitzbitarte III (País Vasco) 33.600-18.400 BP Vol. 5 (Altuna, J., Mariezkurrena, K. \& Ríos, J., Eds.), EKOB Euskal Kultura Ondare Bilduma, Vitoria-Gasteiz: p. 353-373. (in Spanish) ("Provenance of flint from Aitzbitarte-III Cave (Rentería, Gipuzkoa)")

Tarriño, A. 2011b, Procedencia de los sílex de la industria lítica del yacimiento en cueva de Santimamiñe. In: La cueva de Santimamiñe: Revisión y actualización (2004-2006) (López Quintana, J.C., Ed.), Diputación Foral de Bizkaia, Bilbao: p. 281-290. (in Spanish) ("Provenance of flint from Santimamiñe cave (Kortezubi, Bizkaia)")

Tarriño, A. \& Aguirre, M. 1997, Datos preliminares sobre fuentes de aprovisionamiento de rocas silíceas en algunos yacimientos paleolíticos y postpaleolíticos del sector oriental de la cuenca vasco-cantábrica. Veleia, 14: 101-116. (in Spanish) ("Preliminary data of procurement of siliceous rock in some Palaeolithic and Post-Palaeolithic sites at the East of the Basque-Cantabrian basin")

Tarriño, A., Cava, A. \& Barandiarán, I. 2013, Recursos líticos en las industrias del Solutrense Cantábrico: El caso de Altamira (Cantabria, España). Revue Archéologique du Centre de la France 21: 261-272. (in Spanish) ("Lithic resources in the Cantabrian Solutrean assemblages: The Altamira case (Cantabria, Spain)") 
Tarriño, A. \& Elorrieta, I. 2017, Estudio de los sílex recuperados en la zona B de la cueva de Coímbre (Asturias, España). In: La cueva de Coímbre (Peñamellera Alta, Asturias): ocupaciones humanas en el Valle del Cares durante el Paleolítico superior (Yravedra, J. \& Álvarez, D., Eds.), Fundación María Cristina Masaveu Peterson, Madrid: p. 354359. (in Spanish) ("The study of flint finds recovered from Zone B of La Cueva de Coímbre (Asturias, Spain)")

Tarriño, A., Elorrieta, I. \& García-Rojas, M. 2015, Flint as raw material in prehistoric times: Cantabrian Mountain and Western Pyrenees data. Quaternary International, 364: 94108. doi:10.1016/j.quaint.2014.10.061

Tarriño, A. \& Elorza, M. 1989, Estudio geológico del área de Peñacerrada (Álava): Petrografía y cristalografía de las silicificaciones existentes. Cuadernos de Sección de Ciencias Naturales, 5: 43-135. (in Spanish) ("Geological study of the area of Peñacerrada (Alava): Petrography and crystallography of existing silicifications")

Tarriño, A., Muñoz, E., Elorrieta, I., Normand, C., Rasines, P., García-Rojas, M. \& PérezBartolomé, M. 2016, El Sílex en la Cuenca Vasco-Cantábrica y el Pirineo Occidental: Materia prima lítica en la Prehistoria. Cuadernos de Prehistoria y Arqueología de la Universidad de Granada, 26: 129-228. (in Spanish) ("Flint in the Basque-Cantabrian Basin and the Western Pyrenees: Lithic raw material in Prehistory") doi:10.30827/cpag.v26i0.7400

Tarriño, A. \& Terradas, X. 2013, Materias primas líticas. In: Métodos y técnicas de análisis y estudio en arqueología prehistórica. De lo técnico a la reconstrucción de los grupos humanos (García-Díez, M. \& Zapata, L., Eds.), Servicio Editorial de la Universidad del País Vasco, Bilbao: p. 439-452. (in Spanish) ("Lithic raw materials")

Tarriño, A., Yusta, I. \& Aguirre, M. 1998, Indicios de circulación a larga distancia de sílex en el Pleistoceno superior. Datos petrográficos y geoquímicos de materiales arqueológicos de Antoliñako Koba. Boletín de la Sociedad Española de Mineralogía, 21-A: 200-201. (in Spanish) ("Long distance flint tracks at the Upper Palaeolithic. Petrography and geochemical data from the archaeological material from Antoliñako Koba")

Terradas, X. 1995, Las estrategias de gestión de los recursos líticos del Prepirineo catalán en el IX milenio BP: El asentamiento prehistórico de la Font del Ros (Berga, Barcelona). Treballs d'arqueologia, 3: 1-171. (in Spanish) ("Flint procurement in the Eastern Prepyrenees in the IX ${ }^{\text {th }}$ millennia BP”)

Turq, A. 1989, Exploitation des matières premières lithiques et occupation du sols: l' exemple du Moustérien entre Dordogne et Lot. In: INQUA: Colloque du comité français de l'Union internationale pour l'étude du quaternaire. Variations des paléo-milieux et peuplement préhistorique Vol. 13 (Laville, H., Ed.) Cahiers du Quaternaire, CNRS, Bordeaux: p. 179-2014. (in French) ("Lithic raw material exploitation and soil occupation: an example of Mousterian between the Dordogne and Lot")

Turq, A. 1996, L'approvisionnement en matière première lithique au Mousterien et au début du Paléolithique supérieur dans le nord est du bassin aquitain: Continuité ou discontinuité. In: The Last Neanderthals, The First Anatomically Modern Humans: A Tale about the Human Diversity: Cultural Change and Human Evolution: The Crisis at 40 Ka BP (Carbonell, E. \& Vaquero, M., Eds.), Fundació Catalana per a la Recerca: p. 355-362. (in French) ("Lithic raw material procurement at the Mousterian and the begginfs of the Upper Palaeolithic in the Nord of the Aquitaine basin: Continuity or discontinuity") 
A. Prieto et al.

Vita-Finzi, C. 1978, Archaeological Sites in their Setting. Ancient peoples and places Vol. 19. Thames \& Hudson, London, 176 p. 